\author{
SONIA I. OCAÑA RUIZ \\ UNIVERSIDAD JUÁREZ AUTÓNOMA DE TABASCO
}

\title{
Enconchados: gustos, estrategias y precios en la Nueva España
}

$\mathrm{E}$ n la historiografía de la pintura novohispana se advierte cierto vacío respecto a las pinturas incrustadas de concha (ca. I650-I750), hoy conocidas como enconchados. Estas obras menudearon en los inventarios de pintura capitalinos de finales del siglo XVII y principios del XVIII y se conservan numerosos ejemplares de factura esmerada (figs. 2, 4-8 y Iо). Tomás, Juan y Miguel González, ${ }^{\mathrm{I}}$ que al parecer se dedicaron sólo a esta modalidad pictórica, llegaron a trabajar para personajes encumbrados y pertenecieron al gremio de pintores, en el cual tuvieron competidores notables, como Nicolás Correa. Sin embargo, hasta fechas recientes estas obras han ocupado un lugar marginal en los estudios sobre la pintura novohispana. No se ha negado directamente que se trata de pinturas, pero por sus particularidades no ha sido fácil situarlas, de modo que a menudo se han soslayado o se han considerado "artes decorativas".

En la actualidad se conocen más de 250 pinturas incrustadas de concha. ${ }^{2}$ En su mayoría se trata de obras anónimas; sin embargo, 85 ejemplares están

I. Documentalmente se sabe que el padre de Miguel González, Tomás González, hizo obras, aunque no se conocen ejemplares firmados. Véase Guillermo Tovar de Teresa, "Documentos sobre 'enconchados' y la familia mexicana de los González", Cuadernos de Arte Colonial, núm. I (I986): IOI.

2. Numerosos ejemplares pertenecen a colecciones particulares. El mayor registro de obras se encuentra en Marta Dujovne, Las pinturas con incrustaciones de nácar (México: Universidad Nacional Autónoma de México-Instituto de Investigaciones Estéticas, 1984); La concha nácar en México (México: Grupo Gutsa, 1990); María Concepción García Sáiz y Juan Miguel Serrera, "Aportaciones al catálogo de enconchados", Cuadernos de Arte Colonial, núm. 6 
firmados por Miguel y Juan González. Los González hicieron piezas muy conocidas; por ejemplo, una serie de 24 tablas de la Conquista de México (1698) conservada en el Museo de América de Madrid que originalmente perteneció a Carlos II, ${ }^{3}$ así como una serie del mismo tema y número de tablas del Museo Nacional de Bellas Artes de Buenos Aires. La primera está firmada en coautoría por Miguel y Juan González, mientras que la segunda es de Miguel González. Estos artistas han recibido mucha atención, pues distintos estudios se han referido a las series de temática histórica o religiosa ligadas a ellos. ${ }^{4}$

Algunos pintores incursionaron tanto en las pinturas enconchadas como en las que prescinden de ese material. El caso más conocido es el de Nicolás Correa — sobrino de Juan Correa—, que estuvo activo hacia I690, al mismo tiempo que Miguel y Juan González. El trabajo de Correa fue, como se verá, de gran calidad; es decir, los González no monopolizaron la producción de los enconchados de buena factura. También se conservan ejemplares de Agustín del Pino, Pedro López Calderón, un tal Rodulpho y, al parecer, Antonio de Santander. 5

(mayo, 1990): 55-87; México en el mundo de las colecciones de arte. Nueva España I (México: Azabache, 1994) y Rodrigo Rivero Lake, La visión de un anticuario (México: Américo Arte Editores, 1997). El Museo Franz Mayer incluye en su exhibición permanente una Virgen de Guadalupe de Agustín del Pino y otra anónima, así como un San Jerónimo y una Inmaculada Concepción igualmente anónimos. A finales de 2013 el Museo Nacional del Virreinato de Tepotzotlán incluyó en su exhibición permanente seis tablas de una serie de I2 de las Alegorías del Credo de Miguel González, que se suman al biombo enconchado de la Defensa de Viena y a la serie de la Conquista de México, anónimos que ya se exhibían en dicho recinto. También el museo Soumaya ha adquirido obras que exhibe de manera permanente.

3. María Concepción García Sáiz, "La conquista militar y los enconchados. Las peculiaridades de un patrocinio indiano", en Los pinceles de la historia. El origen del reino de la Nueva España (México: Consejo Nacional para la Cultura y las Artes-Instituto Nacional de Bellas Artes, I999), II3.

4. Marta Dujovne, La conquista de México por Miguel González (Buenos Aires: Asociación Amigos del Museo Nacional de Bellas Artes, 1972); María Concepción García Sáiz, "Vida de la Virgen", en Los siglos de oro en los virreinatos de América (Madrid: Sociedad Estatal para la Conmemoración de los Centenarios de Felipe II y Carlos V, 1999), 376-377, "Vida de Cristo", 374 y "La conquista de México", 384-389; México en el mundo, I25-155 y I82-I83; María Concepción García Sáiz, "Precisiones al estudio de la obra de Miguel González”, en Coloquio Internacional Extraordinario. Manuel Toussaint. Su proyección en la historia del arte mexicano (México: Universidad Nacional Autónoma de México-Instituto de Investigaciones Estéticas, 1992), ı05-II6 y Sonia I. Ocańa Ruiz, "Nuevas reflexiones sobre las pinturas incrustadas de concha y el trabajo de Juan y Miguel González", Anales del Instituto de Investigaciones Estéticas XXXV, núm. IO2 (primavera, 2013): 125-176.

5. De Del Pino se conocen, además de la mencionada Virgen de Guadalupe del Museo 
Más aún, desde 1980 han salido a la luz más de cien obras —en su mayoría anónimas - de distintos tamaños y formatos, cuya factura y calidad difieren notablemente en el uso del nácar, así como en el dibujo y el trabajo pictórico. ${ }^{6}$

En conjunto, los ejemplares conservados muestran una diversificación que no resulta tan evidente en las series a las que se han dedicado la mayor parte de los estudios. Esta diversificación es aún más notable en la información documental, pues los documentos referentes a estas pinturas describieron y dieron importancia a aspectos distintos. También consignaron grandes diferencias de precios. Es decir, no hubo un público homogéneo que viera y entendiera las pinturas enconchadas de un mismo modo,7 sino que éstas resultaron de una pluralidad de concepciones e intereses.

La tradición pictórica española de la época admitió muchas técnicas y soportes. El conocido tratado de pintura de Antonio Palomino de 1715 mencionó las pinturas al fresco, al óleo, al temple, bordada, cerífica, aguazo, de porcelana, embutida, férrea, figulina, tejida y vítrea; ${ }^{8}$ modalidades que el Diccionario de Autoridades retomó en la definición de "pintura", en $1737.9 \mathrm{La}$

Franz Mayer, un San Ignacio de Loyola de la colección Mayer de Denver y un San Francisco Xavier (sin firma) a juego con el anterior, del Museo de América de Madrid. De Rodulpho se conserva una Virgen de Guadalupe en el Museo Casa Natal de Jovellanos en Gijón. Las obras de López Calderón y Santander pertenecen a sendas colecciones particulares; del primero es un Nacimiento de la Virgen. Véase García Sáiz y Serrera, "Aportaciones al catálogo de enconchados", 66-74. En 1959 Martín Soria dijo haber visto en la colección de Ramón Aranda una Virgen de Balvanera de Antonio de Santander. Martín Soria, "Painting in Spanish America", en Art and Architecture in Spain and Portugal and their American Dominions 1500-1800 (Baltimore: Penguin Books, 1959), 313. Sin embargo, en 1990 Virginia Armella de Aspe señaló que la obra sólo tenía concha pegada a la orilla de la toca, en el vestido y en todo el ruedo del manto de la Virgen. Armella de Aspe, "La influencia asiática”, en La concha nácar, 83. El mismo año, Tovar de Teresa advirtió: "De no ser porque Soria afirma haber visto un enconchado firmado por este artista, jamás hubiera imaginado que realizaba esta clase de trabajos. Es más, dudo que se trate de Antonio de Santander cuando se alude a la Virgen de Balvanera de la colección de Ramón Aranda." Guillermo Tovar de Teresa, "Los artistas y las pinturas con incrustaciones de concha nácar en México", en La concha nácar, I2O.

6. Véase n. 2.

7. Neil de Marchi y Hans van Migroet, "Art, Value, and Market Practices in the Netherlands in the Seventeenth Century", The Art Bulletin 76, núm. 3 (septiembre, 1994): 45I-464.

8. Antonio Palomino, El museo pictórico y escala óptica, 2 vols. (Madrid: Aguilar Maior, I988 [Ia edición, I715]).

9. Diccionario de la lengua castellana, [...]Tomo quinto. Que contiene las letras O.R. (Madrid: imprenta de Francisco del Hierro, 1737), 278. Consultado en http://buscon.rae.es/, el to de julio de 20II. 
capital novohispana produjo su propia diversidad y dio lugar a obras como la plumaria y los enconchados. Estos últimos se hicieron en un contexto en el que las concepciones pictóricas tradicionales, que comprendían distintas técnicas y materiales, coexistieron con las modernas, basadas en planteamientos técnicos más restrictivos.

La imposición de las concepciones modernas se observa en las Ordenanzas del Gremio de Pintores de 1686, que contemplaron únicamente las obras hechas al óleo, temple y fresco. En los enconchados se usaron temple y óleo, además de pigmentos y procedimientos parecidos a los de las pinturas que prescinden de la concha. ${ }^{\text {Io }}$ Sin embargo, el distintivo uso del nácar fue una innovación tomada de ciertas lacas japonesas, que distingue a los enconchados técnica y formalmente de cualquier otra pintura de su tiempo.

\section{Los origenes}

No sabemos exactamente cómo surgieron los enconchados. En su estudio "Art, Value, and Market Practices in the Netherlands in the Seventeenth Century", Neil de Marchi y Hans van Migroet han advertido que, en el siglo xviI, la pintura neerlandesa experimentó un perpetuo giro innovador, afectado por el acceso de los artistas a nuevas mercancías, tecnologías, fuentes de suministro y formas de organización. A la vez, los mercados fueron los foros y los resultados tentativos del comportamiento interactivo experimental entre muchos individuos y grupos; de ahí que tanto los productos como las estrategias se

Io. Véase Alejandro Huerta Carrillo, Análisis de la técnica y material de dos colecciones de pinturas enconchadas, Colección Textos Básicos y Manuales (México: Instituto Nacional de Antropología e Historia, 199I), y Adelina Illán y Rafael Romero, "La técnica pictórica de los enconchados mexicanos y la problemática de su restauración”, Ciencia y Esencia. Cuadernos de Conservación y Tecnología del Arte, núm. I (2008): 29-46. Hay cierta discusión respecto al uso de los barnices, que en ocasiones se han considerado fundamentales para producir un efecto similar al de las lacas asiáticas. Véase Julieta Ávila Hernández, El influjo de la pintura china en los enconchados de Nueva España, Colección Obra Diversa (México: Instituto Nacional de Antropología e Historia, 1997), 31; Andrés Escalera y Estefanía Rivas, "Un ejemplo de pintura 'enconchada'. La Virgen de la Redonda: estudio radiográfico", Anales del Museo de América, núm. Io (2002): 300-30I y José de Santiago Silva, Algunas consideraciones sobre las pinturas enconchadas del Museo Nacional de Historia (México: Instituto Nacional de Antropología e Historia, 1976), 24. 
modificaran constantemente. ${ }^{\text {II }}$ Los enconchados requirieron de la circulación de las lacas japonesas de exportación namban (muy gustadas en Europa) y de cierto impulso innovador entre los pintores; desde luego, su éxito habría sido imposible si no hubieran captado el interés de los consumidores. El gusto por distintas obras asiáticas, así como por el brillo de ciertos materiales y por la ornamentación se advierte en diversas producciones artísticas, ${ }^{\mathrm{I2}} \mathrm{y}$ dio lugar a soluciones particulares en este caso.

Las incrustaciones de nácar no supusieron una ruptura con la manera de concebir la pintura, sino que agregaron nuevas particularidades a la diversidad de la época. Los enconchados tomaron de las lacas japonesas namban la ornamentación, consistente en fondos negros y figuras doradas e incrustadas de concha, con diseños basados en flores y hojas (fig. I). El desarrollo de la nueva modalidad artística fue producto de las experimentaciones novohispanas, pues la incorporación de la concha al trabajo pictórico en las escenas representadas fue una aportación local. Pese al efecto similar, la técnica de ambas producciones es completamente distinta.

Los enconchados se insertaron con naturalidad en el contexto pictórico novohispano, pese a que no fueron un mero producto de la tradición española. Al contrario, resultaron de un impulso innovador que tomó el gusto por las lacas japonesas como punto de partida para hacer nuevas búsquedas pictóricas. Dicho impulso fue avalado por el gremio de pintores en la práctica, aunque no se contempló en las ordenanzas. Para advertir mejor qué características de los

II. De Marchi y Van Migroet, "Art, Value and Market Prices", 452.

I2. Sobre las apropiaciones del arte asiático en distintos ámbitos americanos, véase XXVII Coloquio Internacional de Historia del Arte. Orientes y Occidentes. El arte y la mirada del otro, ed. Gustavo Curiel (México: Universidad Nacional Autónoma de México-Instituto de Investigaciones Estéticas, 2007), así como Asia and Spanish America: Trans-Pacific Artistic and Cultural Exchange 1500-1850, eds. Donna Pierce y Ronald Otsuka (Denver Art Museum, 2009). Sobre el gusto por los materiales luminosos, véase Mikkel Bille y Tim Flohr Sørensen, "An Anthropology of Luminosity", Journal of Material Culture, núm. I2 (2007): 263-284 y, para la problemática virreinal, Elena Isabel Estrada de Gerlero, "El tesoro perdido de la catedral michoacana”, en La catedral de Morelia, coord. Nelly Sigaut (Zamora: El Colegio de Michoacán/Gobierno del Estado de Michoacán, I99I), I27-I70, así como Alessandra Russo, "Plumes of Sacrifice. Transformations in I6th Century Mexican Feather Art", RES. Anthropology and Aesthetics, núm. 42 (otoño, 2002): 227-250 y Janeth Rodríguez Nóbrega, "El oro en la pintura de los reinos de la monarquía española. Técnica y simbolismo", en Pintura de los reinos. Identidades compartidas, territorios del mundo hispánico siglos XVI-XVIII, coord. Juana Gutiérrez Haces, t. IV (México: Fomento Cultural Banamex, 2009), I315-I375. 
80 SONIA I. OCAÑA RUIZ

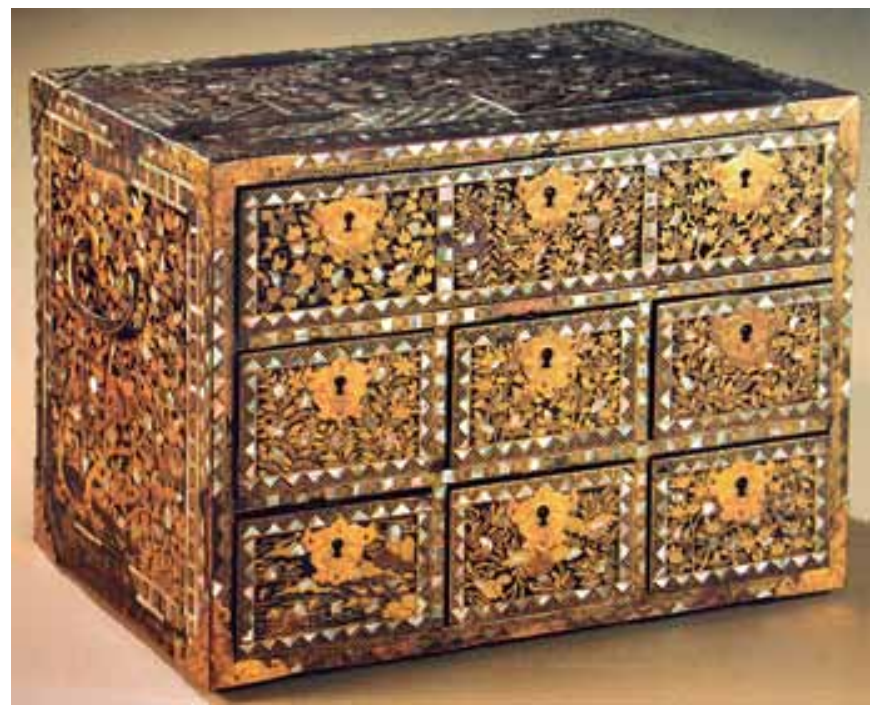

I. Escritorio de laca namban. Castillo de Ambras. Imagen tomada de Oliver Impey y Christiaan Jörg, Japanese Export Lacquer I580-I850 (Ámsterdam: Hotei Publishing, 2005), I2O.

enconchados los acercan a otras pinturas novohispanas y cuáles los aproximan a las lacas namban, se describirán a continuación algunos ejemplares notables.

\section{Las pinturas incrustadas de concha. Características técnicas y formales}

En las obras más minuciosas, la capa de pintura se aplica mediante transparencias que resaltan la luminosidad natural del nácar, cuyas incrustaciones se planean cuidadosamente y se incluyen en el dibujo preparatorio. ${ }^{13}$ Esto se advierte en la serie de I2 tablas de las Alegorías del credo de Miguel González, dividida entre el Museo Nacional del Virreinato de México y el Patrimonio Artístico del Banco Nacional de México. En 1990 Alejandro Huerta estudió la técnica de la tabla San Felipe (fig. 2) de esta serie y halló que el soporte es cedro

I3. Escalera y Rivas, "Un ejemplo de pintura 'enconchada'. La Virgen de la Redonda: estudio radiográfico", 298. 


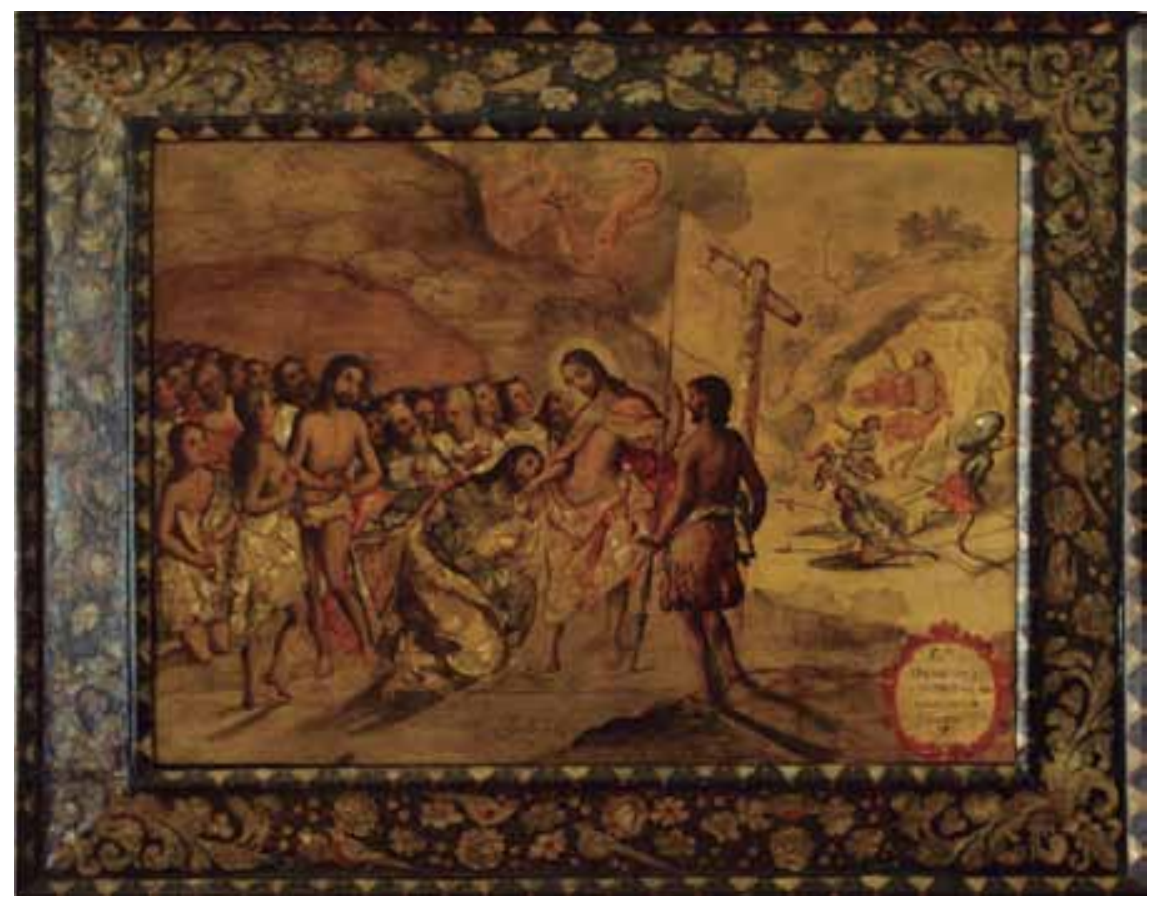

2. Miguel González, San Felipe, serie "Alegorías del Credo", finales del siglo xvII-principios del XVIII, óleo, temple e incrustaciones de concha nácar sobre tabla, 84.8 $\times 106.2 \mathrm{~cm}$ (con marco). Foto: Gloria Minauro. Museo Nacional del Virreinato, Tepotzotlán. Conaculta-INAH-MÉx. "Reproducción autorizada por el Instituto Nacional de Antropología e Historia".

blanco, reforzado en la parte posterior con una tela. ${ }^{14}$ Por el peso del nácar, el mejor soporte de estas obras es la tabla. Todos los ejemplares conservados la usan, misma que en ocasiones se recubre con lienzo.

La base de preparación consiste en una capa porosa de yeso aglutinado con cola animal, ${ }^{15}$ la capa de impregnación también es de cola animal. ${ }^{16} \mathrm{La}$ imprimatura es muy fina y está hecha al temple, de blanco de plomo y blanco de España, con impurezas de negro de carbón. ${ }^{17}$ En la capa pictórica se usan resi-

I4. Huerta Carrillo, Análisis de la técnica, 47. El análisis consistió en la observación con microscopio estereoscópico y la toma de muestras estratigráficas.

15. Huerta Carrillo, Análisis de la técnica, 47.

16. Huerta Carrillo, Análisis de la técnica, 47.

17. Huerta Carrillo, Análisis de la técnica, 48. 
nato de cobre, negro de carbón, blanco de plomo, laca de granza, cinabrio, siena tostado, negro de humo, polvo de oro y sombra natural. ${ }^{18}$ El aglutinante es el temple, excepto en las encarnaciones y el color del pelo, que son oleosos. ${ }^{19} \mathrm{Al}$ parecer, el adhesivo de las placas de nácar es la goma laca. ${ }^{20}$ Se trata de materiales de uso corriente en la pintura novohispana, cuyo uso se adapta para lucir el brillo del nácar subyacente.

El San Felipe ${ }^{2 \mathrm{I}}$ representa sendas escenas correspondientes al quinto artículo del Credo, "descendió a los infiernos y al tercer día resucitó de entre los muertos". La composición guarda parecido con un modelo de Martin de Vos, grabado por Adriaen Collaert hacia I60o (fig. 3). La escena principal es el descenso de Jesús a los infiernos e incluye a Adán, Eva y otros personajes de la Antigua Ley. En el primer plano aparece, de espaldas al espectador, un joven - isan Juan Bautista?- - que sostiene en la mano derecha la cruz y en la izquierda un estandarte con la cruz. La escena secundaria muestra a Jesús saliendo del sepulcro ante cuatro soldados, cuyos expresivos gestos muestran su temor ante el inesperado hecho. A diferencia de la escena principal, ésta tiene un fondo luminoso, para destacar que la resurrección es la culminación del triunfo sobre la muerte.

En todas las tablas de esta serie González introdujo numerosas variaciones compositivas para evitar los desnudos frontales del modelo europeo. Es decir, al margen de su capacidad como artista, se preocupó por hacer obras decorosas, según lo estipulado en las ordenanzas. ${ }^{22}$ Las particularidades de su trabajo se advierten en la articulación entre el brillo del nácar y la paleta restringida, en la que predominan los colores cálidos — sobre todo el amarillo—, así como en el enfático uso de la línea y los marcos ricos. El nácar se embute en pequeños trozos irregulares en las vestiduras de los personajes, sin llegar a conformarlas en su totalidad. La capa pictórica es ligera y permite advertir el brillo

I8. Huerta Carrillo, Análisis de la técnica, 48-50.

19. Huerta Carrillo, Análisis de la técnica, 50 y 5 I. Huerta encontró algunas diferencias en las otras tablas. Por ejemplo, el soporte del "San Andrés" es el pino; la tabla presenta una sinopia roja "aplicada con pintura muy diluida a manera de acuarela", quizá hecha con laca de granza.

20. Huerta Carrillo, Análisis de la técnica, 51. Esta muestra procede de la tabla "Santo Thomás". Según Huerta, no se trata de cola animal.

2I. Sonia I. Ocaña Ruiz, "San Felipe", http://www.virreinato.inah.gob.mx/index.php?option $=$ com_content $\&$ view $=$ article $\&$ id $=235 \&$ Itemid $=$ IO9

22. Manuel Toussaint, Pintura colonial en México (México: Universidad Nacional Autónoma de México-Instituto de Investigaciones Estéticas, I990 [Ia edición, 1965]), 224. 
3. Adriaen Collaert a partir de Martín de Vos, "Descendit ad infernum teria die resurrexit a mortuis", serie del Credo de los apóstoles. Imagen tomada de Marta Fajardo de Rueda, "Del grabado europeo a la pintura americana. La serie El Credo del pintor quiteńo Miguel de Santiago", Revista de Historia Regional y Local 3, núm. 5 (enero-junio, 20II): 203.

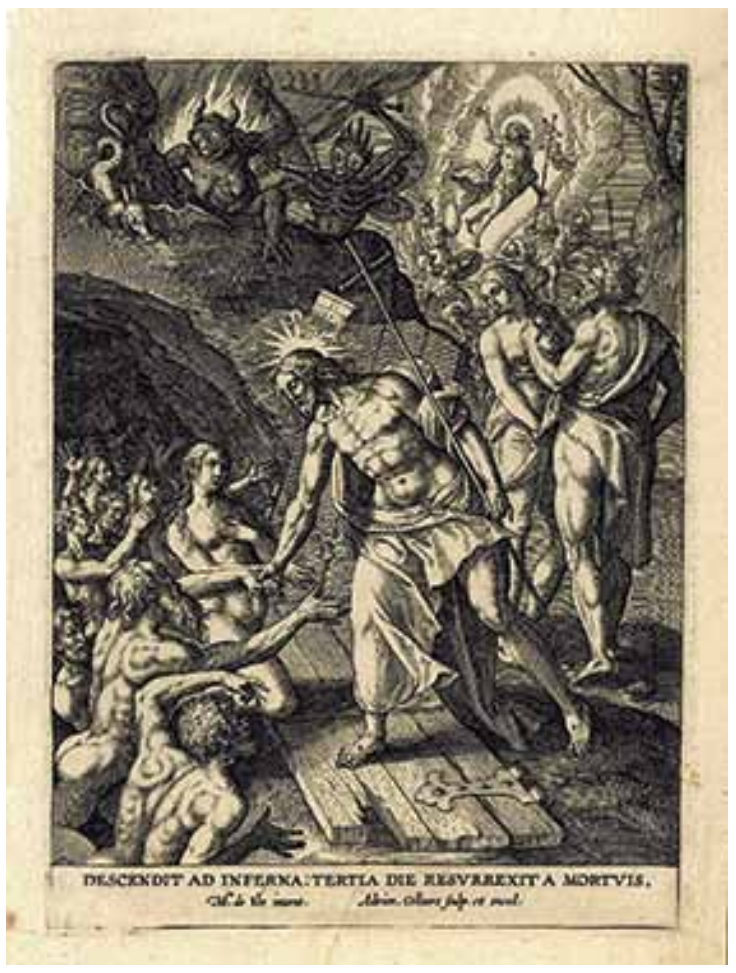

del material orgánico. Las vestiduras están pintadas de amarillo, así como de tonos brillantes de rojo y verde.

González prestó mucha atención al marco, cuyas entrecalles están pobladas por tantas flores, aves y hojas, que apenas se distingue el negro del fondo. Como es habitual, la concepción unitaria de esta serie no se restringió a las escenas, sino que también comprendió los marcos, cuyas soluciones similares los distinguen de otros marcos de este tipo. La mayoría de las aves aparece en reposo, aunque algunas muestran posturas poco naturales. Por ejemplo, en el lado superior del marco de Santiago el Menor, del Banco Nacional de México, se ve una que yace con las alas plegadas y el cuerpo horizontal invertido, de modo que el pecho queda en la parte superior. En el mismo lado se aprecia un ave volando hacia la derecha del espectador, con la cabeza vuelta al lado opuesto. Estas variaciones demuestran que González estuvo muy atento al trabajo de los marcos, seguramente muy apreciados por los comitentes. 
DOI: http://dx.doi.org/10.22201/iie.18703062e.2015.106.2541

84

SONIA I. OCAÑA RUIZ

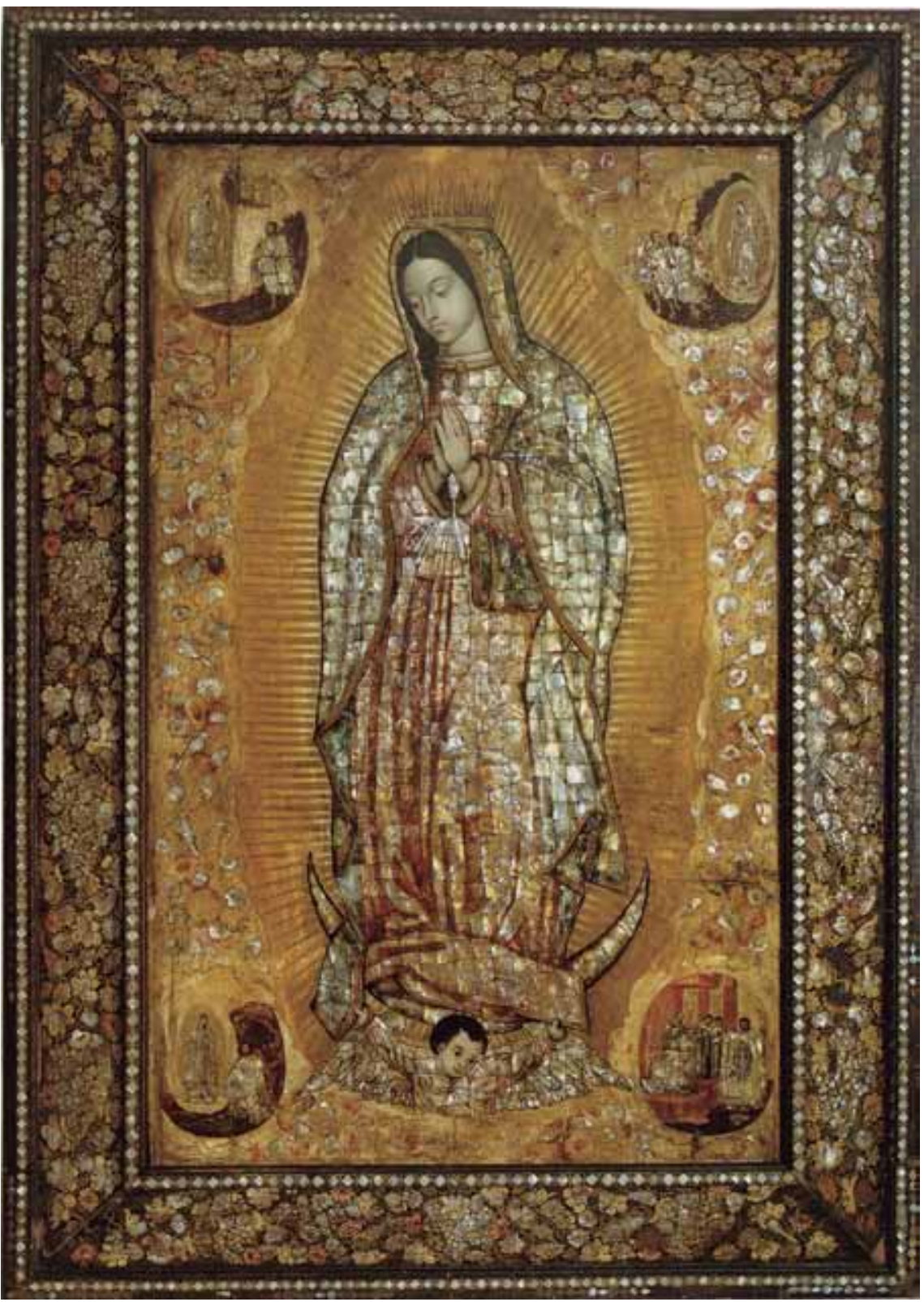

4. a) Anónimo, Virgen de Guadalupe, finales del siglo XVII-principios del XVIII, óleo, temple e incrustaciones de concha nácar sobre tabla, $82 \times 112 \mathrm{~cm}$. Convento de monjas capuchinas de Castellón de la Plana, Valencia. Imagen tomada de Nelly Sigaut, "Virgen de Guadalupe”, en Los siglos de oro en los virreinatos de América (vid supra n. 4), 379. 

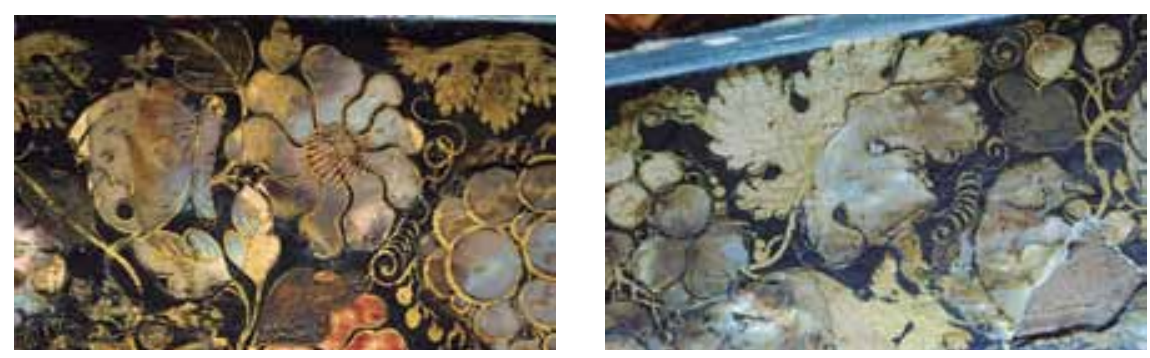

4. b, c y d) detalles.

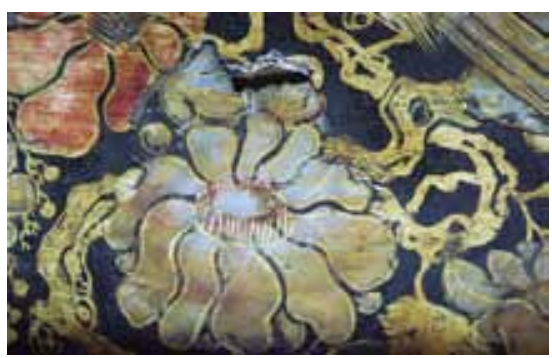

También destacan sendas Vírgenes de Guadalupe anónimas de la parroquia de San José en Tlaxcala y del convento de monjas capuchinas de Castellón de la Plana en Valencia (fig. 4). Ambas son muy similares, pero la de Castellón de la Plana conserva un rico marco enconchado original, mientras que la de Tlaxcala tiene uno moderno. Estas obras muestran una excepcional luminosidad en las ropas de la Virgen, cuyas capas fluidas de transparencias permiten advertir el brillo del nácar subyacente, incrustado en fragmentos regulares. Pocas piezas conservadas exhiben embutidos de concha de formas tan precisas. Sin duda el artista estaba muy familiarizado con este tipo de trabajo, en el que la técnica pictórica se adapta para resaltar la luminosidad.

El marco de la obra de Castellón de la Plana contiene tantos racimos de uvas, flores, hojas, aves y mariposas pintados y embutidos de concha, que hace falta observarlos con mucho cuidado para reconocer las figuras (figs. $4 \mathrm{~b}$ y $4 \mathrm{c}$ ). Algunas flores exhiben un tono desleído de rojo, así como el color natural del nácar, que en el marco no brilla tanto como en la pintura. En las uvas se aprovecha el tono violáceo natural de los fragmentos de concha, mientras que las ramas de los sarmientos están logradas mediante trazos dorados. Es interesante que, a diferencia del marco, la guirnalda que rodea a la Virgen no sea muy 
elaborada; las figuras que la componen están escasamente pintadas, aunque el brillo de la concha contribuye a la luminosidad de la pieza.

\section{El trabajo de las pinturas incrustadas de concha en el contexto gremial}

A finales del siglo XVII, cuando los enconchados alcanzaron su apogeo, los pintores acababan de reorganizar su gremio. Las nuevas ordenanzas (I686) fueron iniciativa de los propios artistas, quienes intentaron proteger su mercado al insistir en la calidad de las obras para propiciar la obtención de beneficios económicos; de ahí que las ordenanzas regulen la venta de pinturas en obradores, calles, plazas, mesones, portales y baratillos. ${ }^{23}$ Desde luego había también reventas y ventas irregulares que el gremio trató de evitar. ${ }^{24}$ Las ordenanzas no dicen nada sobre el trabajo de los enconchados. Sin embargo, en I986 Guillermo Tovar de Teresa dio a conocer dos documentos de 1689 y uno de I699, que demuestran que Tomás, Juan y Miguel González pertenecieron al gremio de pintores. ${ }^{25}$ Asimismo, en 2008 Paula Mues Orts publicó un "Donativo del gremio de pintores y doradores para la Guerra de Sucesión" de la ciudad de México de 1704, que incluye a "Miguel González el conchero" entre los oficiales con tienda. ${ }^{26}$

Al margen de las particularidades de su trabajo, los González deben haber acreditado - según lo establecido en las ordenanzas - su habilidad en el dibujo, colorido y sobre todo en la factura de rostros y cuerpos hermosos y en el decoro de sus obras. ${ }^{27}$ Estos artistas se tomaron muy en serio todas estas cuestiones en sus obras más destacadas. Es decir, su vínculo con el gremio no fue meramente formal, sino que se esforzaron por adaptar su trabajo a las exigencias gremiales.

23. Toussaint, Pintura colonial en México, 224.

24. De ahí la prohibición de "tener tienda de santos de bulto, ni pintura para poderlas revender”. Toussaint, Pintura colonial en México, 224.

25. Tovar de Teresa, "Documentos sobre 'enconchados'”.

26. Paula Mues Orts, La libertad del pincel. Los discursos sobre la nobleza de la pintura en la Nueva España (México: Universidad Iberoamericana-Departamento de Arte, 2008), 395.

27. Toussaint, Pintura colonial en México, 224. Cabe advertir que tanto Tomás como Juan González alcanzaron el grado de maestro, a diferencia de Miguel González. Sin embargo, según el documento de 1704, hallado por Mues Orts, tener el grado de oficial no le impidió encabezar su propio taller, firmar obras y abrir tienda. 


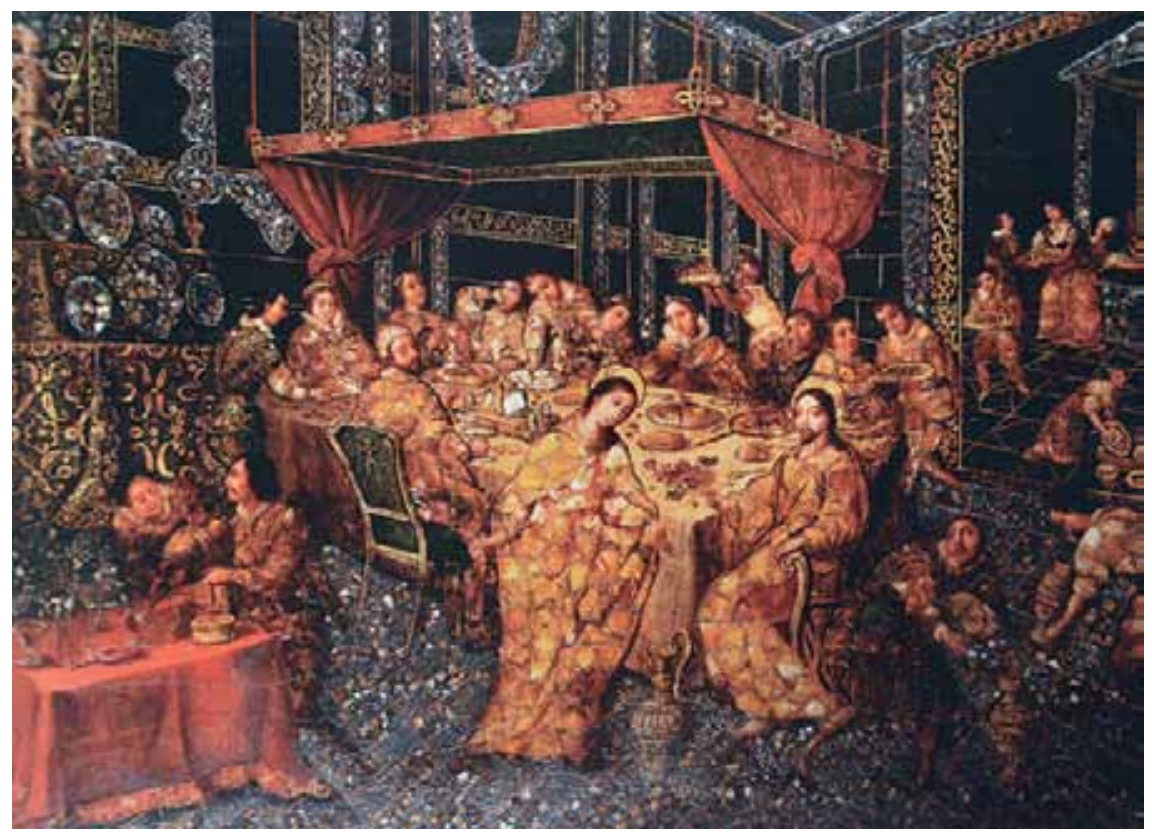

5. Nicolás Correa, Bodas de Caná, I696, ¿̨óleo y temple? e incrustaciones de concha nácar sobre tabla, $57.6 \times 74.8 \mathrm{~cm}$. Hispanic Society of America de Nueva York. Imagen tomada de Stratton-Pruitt, Revelaciones: Las artes en América Latina (vid infra n. 3I), I23.

En términos mercantiles, el éxito se mide en función del lucro. La actitud de los artistas hacia el gremio y el mercado depende de sus circunstancias laborales y económicas. ${ }^{28}$ Como el gremio avalaba la calidad de las obras, el interés de los González por obtener su reconocimiento fue parte de una estrategia que buscó protección y prestigio para facilitar el control de su mercado y de los precios de sus obras. Su estrategia funcionó, pues al parecer acapararon los encargos más importantes, a pesar de que para entonces, artistas como Nicolás Correa incursionaron indistintamente (con éxito) en estas pinturas y las que no emplean la concha.

Los pintores perciben el mercado de forma diferente y adaptan sus estrategias en consecuencia. ${ }^{29}$ Nicolás Correa y más adelante Agustín del Pino hicieron enconchados notables (figs. 5 y 7). Sin embargo, en esta producción

28. De Marchi y Van Migroet, "Art, Value and Market Prices", 458.

29. De Marchi y Van Migroet, "Art, Value and Market Prices", 45I. 


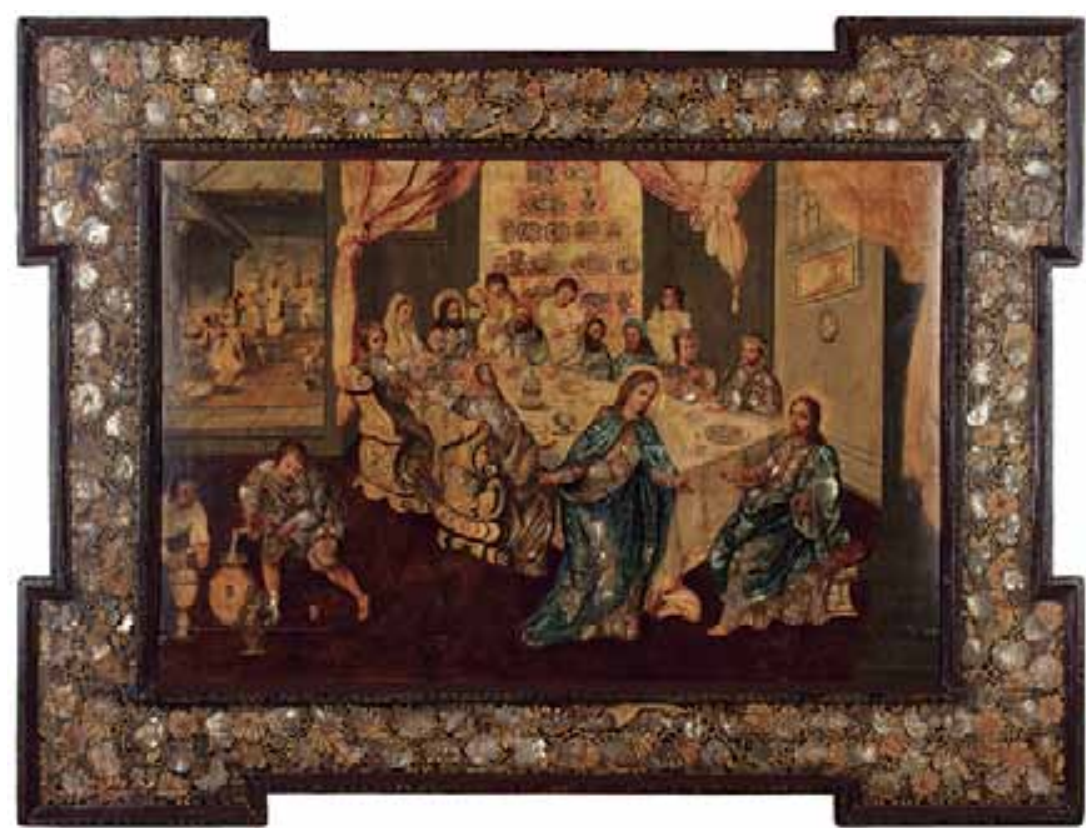

6. Anónimo (atribuido a Miguel o Juan González), Bodas de Caná, serie de la Vida de Cristo, finales del siglo XVII-principios del XviII, ¿óleo y temple? e incrustaciones de concha nácar sobre tabla, $69 \times 102 \mathrm{~cm}$. Museo de América, Madrid, núm. de inv. OOI43.

hubo cierta relación movediza entre fama y calidad. Esto se advierte al comparar una Boda de Caná de Nicolás Correa (1696) conservada en la Hispanic Society of America y otra que pertenece a la serie de 24 tablas de la Vida de Cristo del Museo de América, atribuida a alguno de los González (fig. 6).30

En el aspecto compositivo, ambas obras son muy similares. En la escena principal Jesús preside el banquete nupcial y María aparece de pie a su lado, llamando su atención al vino, servido en primer plano por dos criados. En una escena secundaria se aprecia la actividad de la cocina. ${ }^{3 \mathrm{I}}$ En la tabla atribuida a los González, tanto la escena secundaria como los criados se hallan a la izquierda del espectador, mientras que en la de Correa están a la derecha.

30. Ocaña Ruiz, "Nuevas reflexiones sobre las pinturas incrustadas de concha”, I59-I60.

3I. María Concepción García Sáiz, "Las bodas de Caná", en Suzanne L. Stratton-Pruitt, Revelaciones: las artes en América Latina (México: Fondo de Cultura Económica, 2007), I23 y Ocaña Ruiz, "Nuevas reflexiones sobre las pinturas incrustadas de concha”, I6I-I63. 
7. Agustín del Pino, San Francisco Javier, principios del siglo XVIII, óleo

e incrustaciones de concha nácar sobre tabla, $83.5 \times 6 \mathrm{r} \mathrm{cm}$. Museo de América, Madrid, núm. de inv. 1986/o5/or. Foto: Gonzalo Casas Ortega.

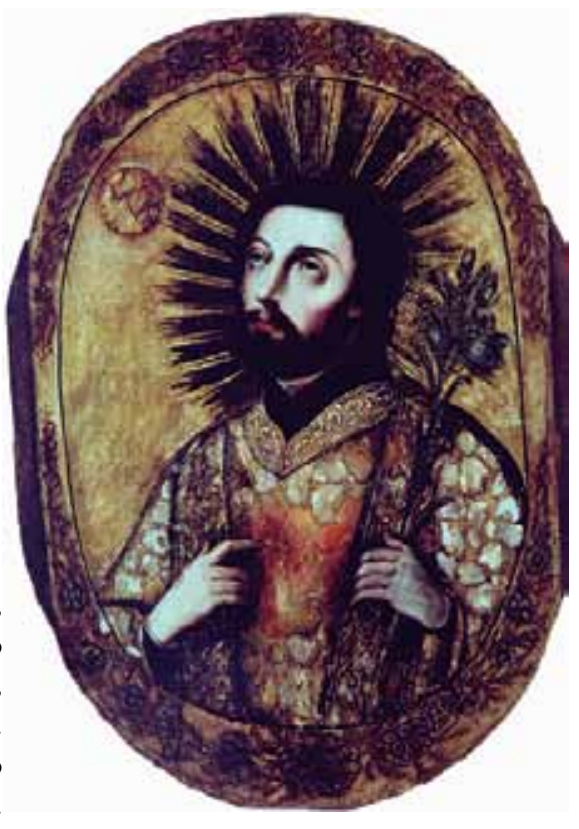

En la tabla de la serie, las vestiduras de todos los personajes están incrustadas de nácar, pero sólo las de Jesús y María están completamente cubiertas del material, embutido en trozos regulares. Además, ambos son los únicos que visten mantos azules, cuyas transparencias muestran el brillo del nácar subyacente. El rico marco contribuye a mantener la atención del espectador. Las figuras son abigarradas y están dispuestas de manera asimétrica. Esta parte de la obra resulta casi tan luminosa como la escena; ahí el brillo del nácar se advierte sobre todo en las flores. También destacan las aves, cuyas cabezas están muy detalladas, pero no hacen referencia a especies reales. Para apreciar mejor estos detalles, es preciso observar las piezas de cerca. Así, la obra contribuye a mantener la atención al plantear sutiles exigencias al espectador.

Correa exhibe mucha familiarización con este tipo de trabajos, a la vez que se aleja de las soluciones de los González. El artista adapta cuidadosamente la labor pictórica para lucir al máximo el brillo del nácar — reservado a la escena, pues la obra no tiene marco enconchado. El efecto es poco común debido al contraste entre el inusual fondo negro y el brillo de los pequeñísimos fragmentos de nácar empleados con profusión. En el muro negro del fondo, 
estos últimos se usan para formar cuadros, mientras que en la parte inferior de la composición simulan un piso marmoleado y a la izquierda se embuten en la vajilla exhibida en el mostrador.

De las más de 250 obras conocidas, ésta es la única que se vale de un fondo negro para potenciar la luminosidad de la concha; al parecer, este recurso no fue usado por los González. Las diferencias entre estas versiones de la Boda de Caná corresponden a gustos distintos respecto al uso del nácar. A la vez, la pintura de Correa demuestra que hacia 1690 la afición por los enconchados estaba lo bastante difundida como para que al menos un artista ajeno a los González estuviera muy familiarizado con este tipo de trabajo, sin abandonar la realización de otras pinturas.

Es decir, los comitentes connotados tuvieron distintas opciones para satisfacer su gusto por este tipo de obras. Sin embargo, a menudo eligieron a los González, cuya reputación parece haber sido superior. En otras palabras, Juan y Miguel González lograron afianzarse en la preferencia novohispana no porque fueran los únicos capaces de hacer buenas obras, sino porque lograron mayor reconocimiento. Además el gusto por los enconchados estuvo lo bastante extendido como para que distintos miembros de la familia González se dedicaran sólo a este tipo de trabajo.

Se ignora con cuánta frecuencia Correa incursionó en esta producción. De las seis pinturas firmadas por él que se conocen, tres poseen incrustaciones de concha y otras tres no. ${ }^{32}$ Todas datan de la década de i690, aunque el artista seguía activo en 1704 - aparece entre los oficiales con tienda en el "Donativo de pintores" de ese ańo localizado por Mues. ${ }^{33} \mathrm{El}$ documento no se refiere a Correa como "conchero", a diferencia de lo que ocurre con Miguel González. Así pues, Correa nunca abandonó la realización de pinturas que prescinden de la concha. Sin embargo, es necesario seguir investigando su producción, pues de momento el escaso número de ejemplares firmados nos impide saber cuán representativos fueron los enconchados de su trabajo, en términos cuantitativos.

32. Los enconchados de este artista incluyen, además de la Boda de Caná, un Camino del Calvario y una tabla que representa Los Cinco Señores. El primero se ofreció en venta al Museo de América en 1948 y se halla en paradero desconocido; el segundo pertenece a una colección particular. Las pinturas que prescinden de la concha son una Multiplicación de los panes y los peces (Museo de América), unos Desposorios misticos de santa Rosa de Lima (Museo Nacional de Arte) y una Virgen del Rosario y santo Domingo de Guzmán (Museo Regional de Querétaro).

33. Mues Orts, La libertad del pincel, 395. 
Puesto que Correa era capaz, como los González, de hacer enconchados notables, cabe afirmar que, aparte de la calidad de sus obras, el prestigio de los González tuvo otras bases. A finales de I680, cuando se acreditaron ante el recién reorganizado gremio, Tomás y Juan González llevaban más de 20 años trabajando. ${ }^{34} \mathrm{Al}$ parecer, la invención de estas obras les corresponde y por un tiempo fueron los únicos capaces de hacerlas. Esto naturalmente les dio ventaja sobre otros artistas y a la vez los limitó a esta modalidad pictórica. Pero hacia 1690, cuando el gusto por los enconchados se había difundido, ya habían surgido buenos competidores. Esto obligó a los González a afianzar su prestigio mediante nuevas estrategias. La reorganización del gremio les permitió obtener un respaldo efectivo para mantener cierta preeminencia entre el mercado de mayor poder adquisitivo.

Tanto la exclusividad del trabajo de los González como la no exclusividad del trabajo de otros artistas emanan de la estrecha relación entre los enconchados y las pinturas que prescinden del nácar. Las obras enconchadas fueron lo bastante diferentes como para que — al margen de la calidad variable de los ejemplares - el mayor reconocimiento correspondiera a los artistas que las habían inventado. Sin embargo, fueron lo bastante parecidas a las otras pinturas como para permitir que algunos artistas incursionaran indistintamente en ambas, con buenos resultados.

\section{Mercados, gustos y precios}

Estas reflexiones se nutren del mencionado estudio de Neil de Marchi y Hans van Migroet sobre arte, valor y prácticas mercantiles en los Países Bajos en el siglo XVII. Pese a centrarse en una problemática distinta, los autores hacen algunas observaciones pertinentes en relación con los enconchados. Las diversas soluciones que exhiben las obras corresponden en parte a la coexistencia de una producción hecha sobre pedido y otra destinada al mercado abierto. La valoración económica podía cambiar si los consumidores tenían un gusto particular por la pintura o si, en cambio, se trataba de individuos poco interesados en el arte, o de comerciantes. ${ }^{35}$

34. Tovar de Teresa, "Documentos sobre enconchados" y García Sáiz, "Precisiones al estudio de la obra de Miguel González”, I90-ııо.

35. De Marchi y Van Migroet, "Art, Value and Market Prices", 45I. 


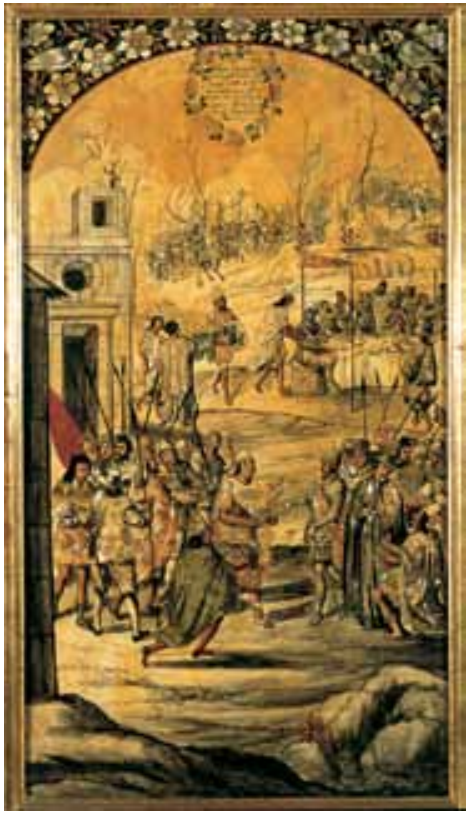

8. Miguel González y Juan González, Manda Cortés quemar y destrozar los idolos que habian quedado, serie Conquista de México, 1698,97×53 cm. Museo de América, Madrid, núm. de inv. ooıo4.

Esto es interesante en relación con nuestras obras, cuyos precios van de 2 reales por dos obras en 1727 a 500 pesos por una serie de diez tablas, en I696. ${ }^{36}$ Tales variaciones difícilmente se explican sólo por el año, la calidad y el tamaño de los ejemplares. Los precios también dependieron de que las obras respondieran a encargos específicos, de que se compraran a un vendedor, al artista en su tienda, o en una almoneda pública.

En 1992, María Concepción García Sáiz señaló las notables diferencias de calidad que exhiben distintas obras de los González —en particular, la serie de la Conquista de México firmada por Miguel y Juan González en I698 (fig. 8) y una serie de al menos ocho tablas de la Vida de san Ignacio de Loyola de Juan González, de 1697, conservada en colecciones de México, España, Argentina y Perú (fig. 9). En esta última, el artista "se ha limitado a reproducir las imágenes que le ofrecen los grabados europeos, a los que copia con una fidelidad cargada de torpeza, llegando al extremo de dividir el espacio de que dispone

36. Véase Archivo General de la Nación de México (en adelante AGN), Civil, vol. I79, exp. 2, I727, f. Io, "Inventario de bienes de Gertrudis Romeo difunta (1727)"; y AGN, Vinculos y Mayorazgos, vol. I70, exp. I, ff. 44-45, "Autos hechos sobre la muerte de la señora dońa Teresa María Retes y Paz Marquesa que fue de San Jorge, inventario y aprecio de sus bienes (I696)”. 


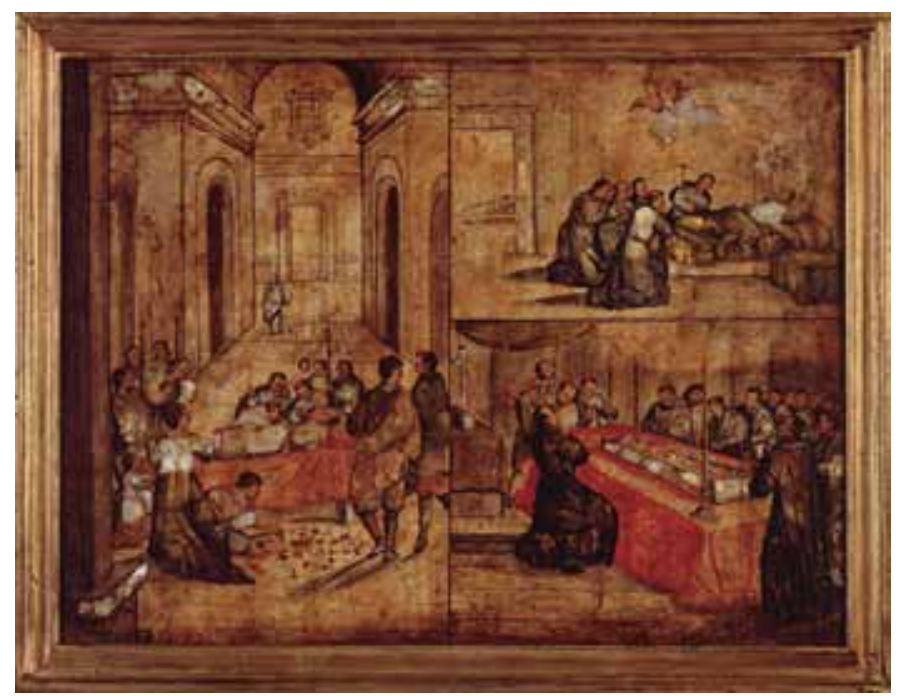

9. Juan González, Muerte y posteriores milagros de san Ignacio, serie "Vida de san Ignacio de Loyola", I697, óleo, temple e incrustaciones de concha nácar sobre tabla, $47 \times 63 \mathrm{~cm}$. Museo Pedro de Osma Lima.

de forma que las escenas queden aisladas, con lo que evita incorporar nuevos elementos a la composición." 37

Así pues, llama la atención que apenas un año después, la serie histórica exhiba "dominio del dibujo a mano alzada y composición de los grupos [...] trazos ágiles y seguros que sirven para definir contornos y dar movilidad a las figuras [así como] las suaves transparencias que caracterizan a los mejores enconchados." ${ }^{8}$ El contraste resulta de especial interés al tratarse de obras de madurez. Como los artistas podían hacer personalmente un número limitado de piezas, en ocasiones sólo daban un toque al trabajo de taller. Tal podría ser el caso en la Vida de san Ignacio de Loyola, cuya falta de soltura la aleja de las otras pinturas de Juan González de la época. En mi opinión, el contraste de factura responde al uso de distintas estrategias, destinadas a satisfacer diferentes necesidades

37. García Sáiz, "Precisiones al estudio de la obra de Miguel González", iıo-III. Las novedades respecto al modelo son "ciertos elementos decorativos, como en el adorno del barco en que Ignacio abandona España, tras arrojar a la orilla de la playa sus últimas monedas; una enorme banderola de rizados vuelos y un mascarón profusamente ornamentado."

38. García Sáiz, "Precisiones al estudio de la obra de Miguel González", iII. 


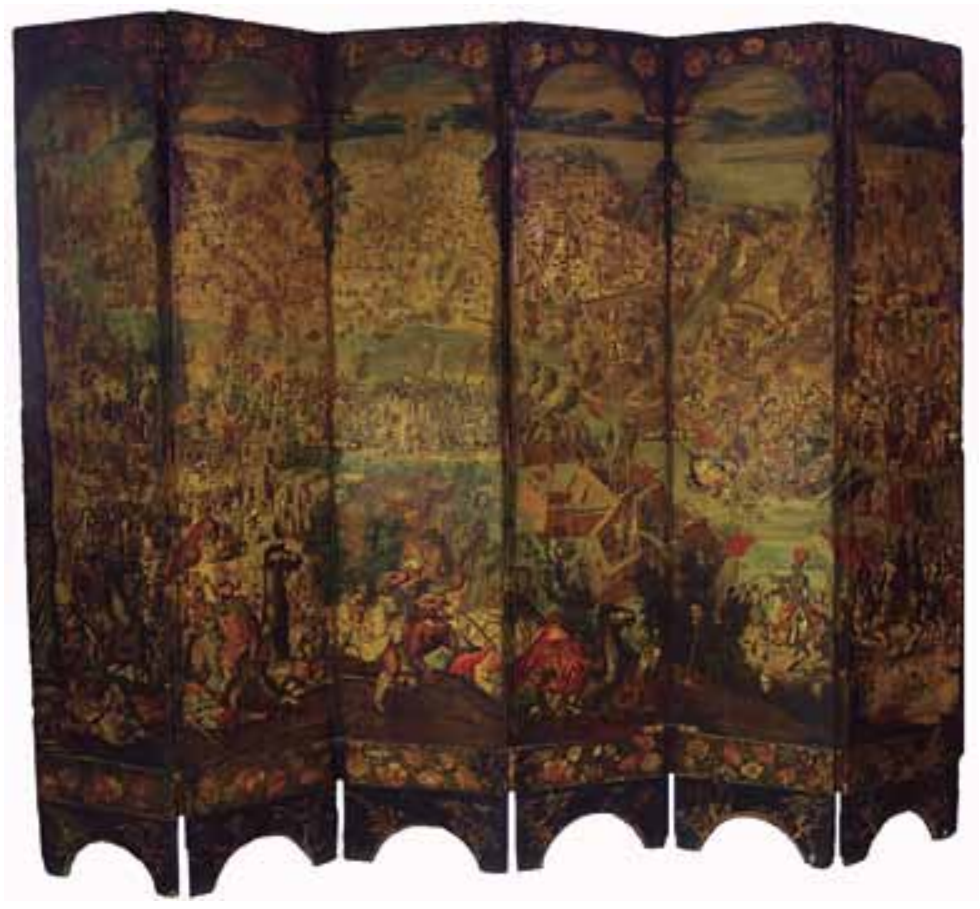

Io. Anónimo (atribuido a Miguel o Juan González), biombo que representa la Batalla de Viena (1683) y montería, $48 \times 228 \mathrm{~cm}$. Doce hojas y dos haces. Museo Nacional del Virreinato, Tepotzotlán. Foto: Gloria Minauro. Conaculta-INAHMÉx. "Reproducción autorizada por el Instituto Nacional de Antropología e Historia"

de consumo. Es decir, una de las claves del éxito de los González fue su capacidad de adaptarse a los gustos y posibilidades económicas de distintos clientes.

Incluso en sus obras más logradas, los González a menudo se ciñeron a los grabados que les sirvieron de modelo, como en el biombo dividido entre el Museo Nacional del Virreinato de México y el Brooklyn Museum (figs. Io y II), que muestra dominio técnico tanto en el dibujo, como en el trabajo pictórico y el de incrustación. En otras ocasiones, los artistas deliberadamente introdujeron variaciones compositivas. Por ejemplo, en las series de la Conquista de México resolvieron las escenas de maneras distintas, aunque se trate de los mismos episodios. ${ }^{39} \mathrm{El}$ tema representado y el rápido envío a prominentes

39. García Sáiz, "La conquista militar y los enconchados", I2I-I22. 


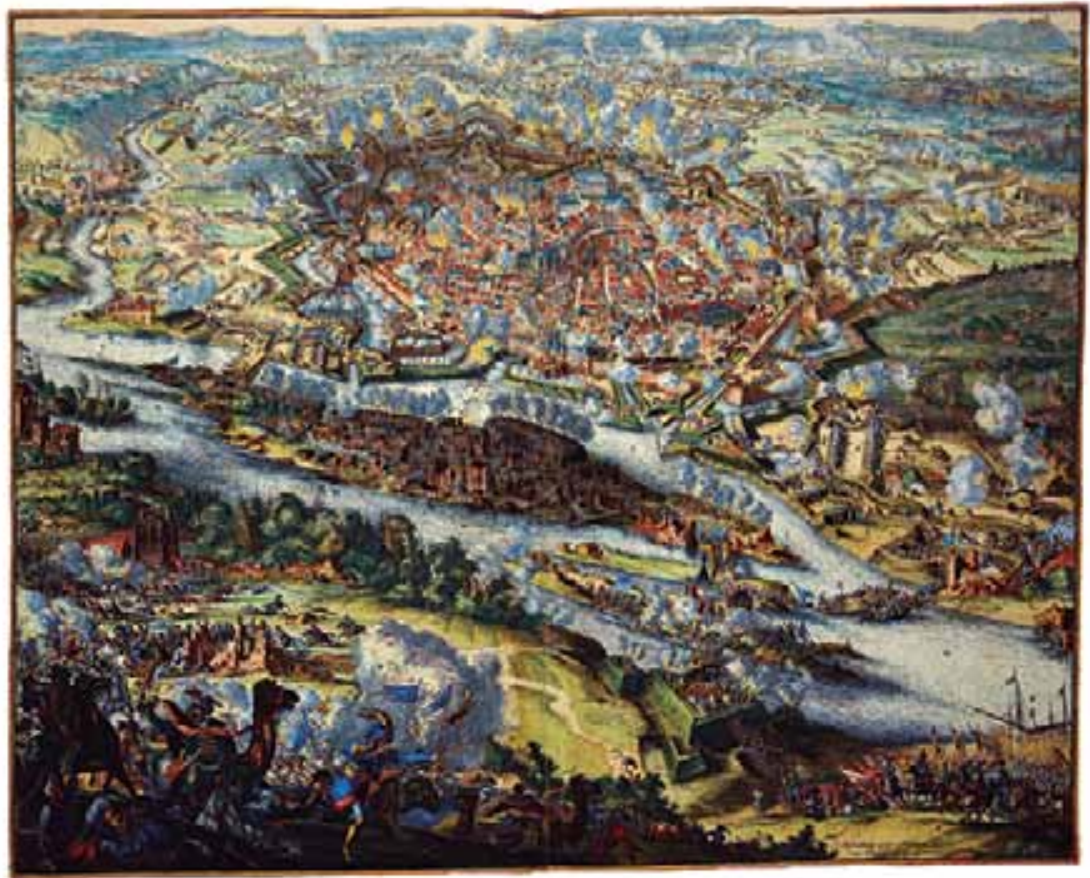

II. Romeyn de Hooghe, El sitio de Viena por los turcos, I683, publicada en el Atlas Van der Hagen, ca. 1690. Imagen tomada de Behind Closed Doors. Art. in the Spanish American Home, I492-I898 (Brooklyn y Nueva York: Brooklyn Museum/The Monticelli Press, 2013).

colecciones europeas sugieren que se trató de obras hechas por encargo. Así, la individualidad de las soluciones, lejos de ser casual, debió acordarse por los comitentes y los artistas.

No es fácil saber hasta qué punto las soluciones originales se valoraron económicamente. De Marchi y Van Migroet han advertido que los artistas neerlandeses enfatizaron cuando se trataba de obras originales (más apreciadas por el público), para aumentar el precio, así como el reconocimiento a su trabajo. ${ }^{\circ} \mathrm{L}$ La problemática novohispana tuvo sus propias particularidades $\mathrm{y}$, aunque en ocasiones se valoró la originalidad compositiva, ésta se planteó en términos distintos a los neerlandeses. ${ }^{4 \mathrm{I}}$ Aún así, la originalidad requirió un esfuerzo

40. De Marchi y Van Migroet, "Art, Value and Market Prices”, 456.

4I. Al respecto véase Clara Bargellini, "Difusión de modelos: grabados y pinturas flamencos e italianos en territorios americanos", en Pintura de los reinos. Identidades compartidas, 
adicional que habría permitido a los artistas aumentar su prestigio y obtener mayor beneficio económico. ${ }^{42}$

Respecto a lo que los consumidores pudieron haber apreciado en las obras hechas sobre pedido, una de las mejores fuentes de información se encuentra en un contrato de Juan González de I699, que ofrece muchos datos sobre la relación entre la calidad y el precio de las mismas:

Primeramente contratan y se obligan el dicho Juan González a hacer y entregar al dicho [factor], trece láminas de pintura y embutido, de concha de a vara y cuarta en cuadro, y han de ser de la misma calidad y embutido de una de san Antonio que se ha hecho para muestra y está en poder de dicho Juan González, pagada por el dicho factor, para que sirva de pauta y regla para las demás que ha de hacer de la historia e imágenes que se le pidiere. Y así estar referidas acabadas quedan ajustadas en el precio de veinte y seis pesos cada una, que le ha de pagar el dicho factor. Asimismo ha de hacer otras catorce láminas unas medianas del tamaño y forma de otra que se ha hecho para muestra de la imagen de Nuestra Señora de la Concepción, de vara y cuarta de largo y una vara de ancho, con la misma calidad de embutido, pero en la pintura, la historia e imágenes que le pidiere dicho factor y constarán unas y otras por memoria firmada de su nombre; y estas conclusas y acabadas, se le han de pagar al dicho Juan González, al precio de veinte pesos cada una, entendiéndose que se han de cotejar con las muchas referidas, y estando como ellas en el embutido y flores que tienen, las ha de recibir el dicho factor por el dicho precio, y si no fueren de esa calidad, no ha de ser obligado a recibirlas. ${ }^{43}$

El hecho de que Juan González hubiera hecho una obra de muestra para este encargo sugiere que el comitente apreció el trabajo no sólo por la reputación del artista —el año anterior Juan y Miguel González habían hecho una serie destinada a Carlos II- sino también por la calidad que esperaba de las piezas. De Marchi y Van Migroet han advertido que en los Países Bajos las autorías se ligaron íntimamente a la innovación y a los precios de las obras y a que el valor mercantil del arte correspondió, más que a su valor intrínseco, a la reputación del artista. ${ }^{44} \mathrm{Y}$, aunque González estaba consciente de la importancia

territorios del mundo hispánico siglos XVI-XVIII, 965-IO05.

42. De Marchi y Van Migroet se han referido a la capacidad de "diferenciación creativa", que en Europa fue necesaria para aumentar la valoración del trabajo, lo cual se reflejó en términos económicos. Véase "Art, Value and Market Prices", 452.

43. Tovar de Teresa, "Documentos sobre enconchados", Ior. Las cursivas son mías.

44. De Marchi y Van Migroet, "Art, Value and Market Prices", 455-456. 
de la firma para su prestigio personal, ${ }^{45}$ en su contrato los ejemplares se valoran a partir de su calidad.

Parte de la información documental debe leerse entre líneas. Tanto el brillo como el parecido con las lacas son temas importantes a los que rara vez hay referencias específicas. Ahora bien, en el contrato de 1699 la calidad de las obras se relaciona explícitamente con el trabajo de pintura, embutido y flores. La insistencia en la calidad del embutido demuestra que el factor prestó mucha atención al uso de la concha, cuya principal cualidad es su brillo.

Los consumidores deben haber valorado en especial los enconchados que usaron teselas regulares de nácar para conformar ciertos elementos compositivos en su totalidad. A menudo esos ejemplares exhiben un brillo notable, gracias al uso de transparencias en la capa pictórica. Esto se advierte en las mencionadas Vírgenes de Guadalupe de Castellón de la Plana (fig. 4) y Tlaxcala. Es lógico suponer que el precio de las obras se ajustó en función del esfuerzo adicional requerido por este tipo de trabajo.

Respecto al parecido entre estas pinturas y ciertas lacas, las referencias se hallan implícitas en las frecuentes menciones a los marcos embutidos de concha. Las flores mencionadas en el contrato de 1699 deben de haberse localizado en marcos o cenefas. Muchos marcos enconchados exhiben diseños similares a los de las lacas namban (en los que abundan las flores). Esto sugiere que no sólo los marcos "de concha y maque", sino también muchos de los que los documentos refieren únicamente como "marcos de concha", tuvieron diseños parecidos a los de los ejemplares conservados. ${ }^{46}$ En esta investigación se localizaron menciones documentales a 244 pinturas enconchadas. Muchas partidas omiten los marcos; sin embargo, cuando éstos se aluden, en su mayoría se trata de los de concha. Los documentos registran 98 ejemplares con marcos de concha y sólo I4 de otro tipo — negros, dorados, de ébano, pintados de añil.

Por otro lado, en el contrato el precio de las obras varía en función de su tamaño. Las dos pinturas que sirvieron de muestra deben de haber sido de

45. La serie de la Conquista de México de 1698 es la única firmada en coautoría y es probable que los González supieran a quién estaba destinada y aprovecharan el importante encargo para afianzar su reputación. Ocańa Ruiz, "Nuevas reflexiones sobre las pinturas incrustadas de concha”, I5O-I52.

46. Desde luego, los diseños varían en algunas obras. Por ejemplo, una Inmaculada Concepción y un San José con el Niño anónimos, del monasterio de las Descalzas Reales de Madrid, poseen ricos marcos de concha, ajenos al trabajo de incrustación y pictórico. Véase Nuria Salazar, "Inmaculada" y "San José con el Niño", en México en el mundo, I48-I49. 
calidad similar, pero la que medía aproximadamente $104.5 \mathrm{~cm}$ "en cuadro" se tasó en 26 pesos, mientras que la que medía cerca de $104.5 \mathrm{~cm}$ de alto por 83.59 $\mathrm{cm}$ de ancho se valuó en 20 pesos. ${ }^{47}$ Estos precios son de interés, pues se trató de tablas nuevas de buena calidad, hechas sobre pedido por un artista prestigiado en el apogeo de la producción. Sin embargo, como la producción y el consumo se diversificaron, no es posible sacar conclusiones que sean válidas para todos los casos.

Por importante que fuera el trabajo de los González, no hay duda de que la elaboración, así como el gusto por las obras, los trascendió. Estas pinturas nacieron vinculadas a Tomás González —el padre de Miguel González—y a su pariente Juan González. Pero el reconocimiento del gremio implicaba cierta relación con otros pintores y es probable que en los talleres de los González hubiera oficiales y aprendices. La incursión de artistas como Nicolás Correa en estas obras permite afirmar que hacia I690 la difusión de esta modalidad pictórica ya contaba con distintos agentes.

Agustín del Pino y Pedro López Calderón estuvieron activos después de los González. Se sabe poco de estos artistas. La actividad de López Calderón, así como la de Del Pino, están documentadas en $1720.4^{8}$ Pero es probable que la actividad de Del Pino haya empezado más de 20 años antes. Gabriela Sánchez Reyes localizó una diligencia probatoria para contraer matrimonio (I705) de Agustín del Pino, "español viudo". El documento no menciona el oficio de Del Pino, pero sí el de su testigo Tomás de Sosa, mulato libre y maestro de pintor. ${ }^{49} \mathrm{Al}$ igual que Correa, Del Pino y López Calderón deben haber incursionado en los enconchados para aumentar sus ingresos al diversificar su mercado. Desde luego, para conocer mejor las diferencias entre su trabajo

47. Aunque al parecer se trata de ejemplares no conservados, cabe advertir que las medidas de la primera obra son parecidas a las de una Virgen de Guadalupe de Miguel González $(\mathrm{I} 24.4 \times 95.2 \mathrm{~cm})$, del Los Angeles County Museum of Art. La obra se reproduce y comenta en la página web del Los Angeles County Museum of Art: http://collections.lacma.org/ node/222405, así como en Ocaña Ruiz, "Nuevas reflexiones sobre las pinturas incrustadas de concha”, 156 .

48. García Sáiz y Serrera, "Aportaciones al catálogo de enconchados", 66-70. En 1984, Marta Dujovne se refirió a la Virgen de Guadalupe de Del Pino y señaló: "Según La pintura mexicana, siglos XVII-XVIII. Colecciones particulares [...] Agustín del Pino [está] documentado en México en 1727 y 1728". Dujovne, Las pinturas con incrustaciones de nácar, 59.

49. Gabriela Sánchez Reyes, "Los mulatos en el gremio de pintores novohispanos: el caso de Tomás de Sosa, $c a$. 1655-ca. 1712", Boletín de Monumentos Históricos, tercera época, núm. I3 (mayo-agosto, 2008): 8. 
y el de los González es necesario estudiar la técnica de los ejemplares firmados por aquéllos. ${ }^{\circ}$

El trabajo de López Calderón y —al parecer- el de Del Pino corresponden a la última etapa de la producción, que hasta ahora se ha estudiado poco. Una de las razones para analizarla es que fue lo bastante importante como para incluir ejemplares hechos por encargo. La obra más tardía conocida es una Virgen de Guadalupe anónima, de colección particular, cuya inscripción reza: "A devoción de Manuel Pérez de la Paz y Motezuma y su mujer Bárbara Lopez de Huetor año 1734 ". ${ }^{51}$ La familia Moctezuma había encargado enconchados a los González durante la gestión de José de Sarmiento y Valladares, conde de Moctezuma (por su primer matrimonio con María Jerónima Moctezuma y Jofre de Loaisa) como virrey de la Nueva Espańa de 1696 a I70I..$^{52}$ La actividad documentada de los González concluyó en 1704 y existen pocas evidencias de obras hechas sobre pedido después de su muerte. Sin embargo, la Virgen de Guadalupe de 1734 demuestra que para entonces los consumidores interesados en ellas aún tenían al alcance el trabajo de artistas a los que apenas conocemos.

\section{¿Buena calidad y precios altos?}

La información que aquí se analizará procede de inventarios de bienes y cartas de dote. En algunos casos se trata de fuentes primarias inéditas, aunque también se discutirán menciones documentales previamente publicadas en distintos textos. ${ }^{53}$ De gran interés resulta el inventario de bienes de Teresa Francisca María de Guadalupe Retes Paz Vera, marquesa de San Jorge, de I696. El documento lo localizó y estudió el investigador Gustavo Curiel, quien se ha refe-

50. Las obras de los González se han estudiado técnicamente en Huerta Carrillo, Análisis, y en Illán y Romero, "La técnica".

5I. La obra se registra y reproduce en Dujovne, Las pinturas con incrustaciones de nácar, 6o-6I.

52. Antonio Bonet Correa, "Un biombo del siglo XVII", Boletín del INAH, núm. 2I (septiembre, 1965): 33 y Dujovne, La conquista de México por Miguel González, 8.

53. Para distinguir las menciones documentales ya publicadas de las localizadas en esta investigación, cuando se trate de menciones publicadas se dará el crédito al autor en las notas a pie de página; cuando se trate de fuentes inéditas, se citará el fondo documental. Algunos documentos ofrecen mucha información, en la que se ahondará, mientras que en otros casos se analizarán de modo general los datos desprendidos de un conjunto de documentos. 
IOO

SONIA I. OCAÑA RUIZ

rido al excepcional poder económico de la familia Retes. ${ }^{54}$ La marquesa tuvo 2 IO pinturas, de las cuales 26 estaban incrustadas de concha. Las obras se describieron como:

Diez láminas de concha con marcos de concha y maque, vara y cuarta de alto, Vida de Nuestra Señora la Virgen María, 50 pesos cada una, montan 500 pesos. I5 láminas de concha de diferentes tamańos y advocaciones con marcos de maque y concha, montan I5o pesos en total. I lámina de concha con marco de lo mismo y maque, Glorioso san Esteban, poco menos de vara, 25 pesos.55

El documento también mencionó una mesa pintada de concha con varias figuras, de vara y dos tercias de largo y travesaños de fierro, apreciada en 25 pesos, que seguramente se hizo en un taller de pintura familiarizado con el trabajo de enconchados. ${ }^{56}$

El contrato de Juan González de 1699 permite apreciar en su justa medida la calidad de las obras de dońa Teresa Retes. La diferencia entre ambos documentos es de apenas tres años; más aún, el contrato se refiere a obras nuevas y de buena calidad encargadas a un artista prestigioso. En el inventario de la marquesa de San Jorge, las diez pinturas tasadas en 500 pesos midieron lo mismo que las obras mencionadas en el contrato, cuyo precio duplicaron. Entre los documentos novohispanos conocidos, éste es el que registra los costos más altos en relación con estas pinturas. Sin duda la serie de la marquesa tuvo buena factura, aunque es difícil precisar hasta qué punto el alto precio se debe a la calidad excepcional o al gusto particular de este personaje por esta producción. Como el trabajo de los González se adaptaba a las exigencias de los consumidores, para esta serie se podrían haber hecho requerimientos concretos - por ejemplo, un trabajo especialmente rico en los marcos de concha y maque- que incidieran en el precio.

54. Gustavo Curiel, "El efímero caudal de una joven noble. Inventario y aprecio de los bienes de la marquesa dońa Teresa Francisca María de Guadalupe Retes Paz Vera (ciudad de México, I695)", Anales del Museo de América, núm. 8 (2000): 65-Ior.

55. AGN, Vinculos y mayorazgos, vol. 170, exp. I, ff. 44-45, "Autos hechos sobre la muerte de la señora dońa Teresa María Retes y Paz marquesa que fue de San Jorge, inventario y aprecio de sus bienes (I696)".

56. Véanse ejemplos de este tipo de trabajo en Gustavo Curiel, "Alegoría de Atlas con Vulcano", en México en el mundo, I82-I83 y en Elisa Vargaslugo, "Sagrario exento", en México en el mundo, 154 . 
Al margen de las posibilidades económicas de dońa Teresa, su gusto por estas obras es evidente, pues los enconchados componen más de io por ciento de su colección pictórica. La pintura de mayor precio de este inventario fue una imagen del Señor san Miguel con marco de ébano; como la serie enconchada de la Vida de la Virgen, midió vara y cuarta de alto (aprox. $104.5 \mathrm{~cm}$ ), pero triplicó su precio, pues se valuó en 150 pesos. ${ }^{57}$ Dos láminas "bordadas de coral" de tres cuartas de alto $(63 \mathrm{~cm})$ se tasaron en 160 pesos, ${ }^{58}$ mientras que las otras pinturas alcanzaron un máximo de 50 pesos. 59 Es decir, las tablas de la Vida de la Virgen se contaron entre sus pinturas más valoradas.

Por su parte, el San Esteban midió poco menos de $83.59 \mathrm{~cm}$ y se tasó a 25 pesos. Sin duda se consideró también de buena calidad, pues el contrato de Juan González se refirió a obras de medidas similares (IO $4.5 \mathrm{~cm}$ de alto por $83.59 \mathrm{~cm}$ de ancho), tasadas a 20 pesos. La cuestión no resulta tan clara en el caso de las 15 láminas de distintos tamańos y advocaciones, valuadas en 150 pesos en total, pues el inventario de bienes advierte la presencia de marcos de maque y concha, pero omite otros detalles que pudieran tener incidencia en el precio.

Gustavo Curiel señaló que a la muerte de la marquesa de San Jorge, sus familiares emprendieron una agria disputa por sus bienes. ${ }^{60}$ En esta investigación se localizó el inventario de bienes del contador Bentura de Paz (I704), tío carnal de la marquesa (era hermano de su madre), ${ }^{6}$ que había estado presente en las diligencias de recopilar y avaluar sus cuantiosos bienes. ${ }^{62}$ El documento de Bentura de Paz menciona muchos objetos que originalmente pertenecieron a la marquesa, incluyendo el lote de enconchados. Es interesante advertir que numerosos objetos provenientes del inventario de 1696 habían sufrido una notable depreciación. ${ }^{63}$

57. Curiel, "El efímero caudal", 78.

58. Curiel, "El efimero caudal", 78.

59. Curiel, "El efímero caudal", 78.

6o. Curiel, "El efímero caudal", 65-68.

6I. María Teresa Huerta, "Los Retes: prototipo del mercader de plata novohispana en la segunda mitad del siglo XvII", en Los vascos en las regiones de México. Siglos XVI a Xx, coord. Amaya Garritz, t. III (México: Universidad Nacional Autónoma de México-Instituto de Investigaciones Históricas/Ministerio de Cultura del Gobierno Vasco/Instituto VascoMexicano de Desarrollo, 1997), 85.

62. Curiel, "El efímero caudal", 66.

63. agn, Civil, vol. 179, exp. 8, f. 30, "Bienes del contador don Bentura de Paz (1704)". 
IO2

SONIA I. OCAÑA RUIZ

La serie de la Vida de la Virgen, que en 1696 se había valuado en 500 pesos, se tasó en 250 pesos. ${ }^{64}$ El San Esteban que había costado 25 pesos se valuó en I2 pesos; siete tablas del grupo de is "de distintos tamaños y advocaciones" se valuaron en cinco pesos y las otras ocho en diez pesos cada una - estas últimas son las únicas que mantuvieron su precio original. La mesa pintada y con embutidos de concha alcanzó diez pesos; es decir, menos de la mitad de su valor original. ${ }^{65} \mathrm{La}$ descripción de las obras es casi idéntica a la del inventario de 1696, lo que sugiere que mantenían un estado similar. Así pues, la relación entre calidad y precios podía ser volátil: en cortos periodos de tiempo, las mismas piezas podían dar lugar a grandes variaciones, en términos de apreciación económica.

En la investigación de la que surge este texto se localizaron numerosos inventarios de bienes ricos, con colecciones pictóricas importantes, que no incluyeron enconchados. Incluso entre quienes sí gustaron de las obras, el aprecio varió de manera notable, pues algunos personajes encumbrados gustaron de ellas pero no exhibieron un interés tan pronunciado como el de la marquesa de San Jorge. De Marchi y Van Migroet han advertido que la actitud de los consumidores hacia las obras no necesariamente dependía del poder adquisitivo, aunque desde luego éste podía ser una restricción. ${ }^{66}$ Esta observación es pertinente en relación con las pinturas incrustadas de concha, pues enseguida se verá que ciertos personajes muestran mucho interés por este tipo de obras, a pesar de que su poder adquisitivo no es tan alto como en los casos que se acaban de discutir.

64. "Ytem diez láminas de concha con marcos de lo mismo de vara y cuarta de alto de la Vida de la Virgen Nuestra Señora cada uno a veinte y cinco pesos montan doscientos cincuenta pesos." AGN, Civil, vol. 179, exp. 8, f. 30, "Bienes del contador don Bentura de Paz (I704)".

65. "Ytem otra lámina y marco de concha del Glorioso san Esteban de poco más de vara en doce pesos". "Ytem quince láminas de concha de diferentes tamańos y advocaciones con sus marcos de maque y concha; los siete apreciados a cinco pesos, montan treinta y cinco pesos. Y los ocho complemento a las quince, declaró dicho contador, haberlos vendido a diez pesos, importa todo ciento quince pesos". "Ytem una mesa pintada de concha con varias figuras, de vara y dos tercias de largo y atravesaños de fierro apreciada en diez pesos", AGN, Civil, vol. I79, exp. 8, ff. 36v y 39v.

66. De Marchi y Van Migroet, “Art, Value and Market Prices”, 457. 


\section{Expansión del gusto y diversificación}

El inventario de bienes del difunto capitán Joseph Olmedo y Luján (I708) menciona IO5 pinturas, de las cuales I2 estuvieron incrustadas de nácar. La pintura de mayor precio de este inventario se tasó en 70 pesos, ${ }^{67}$ pero la mayoría no alcanzó io pesos. Los costos de los enconchados van de 24 pesos por dos obras a 20 reales por otras dos. ${ }^{68}$ Las diferencias de tamaño entre los ejemplares de mayor y menor monto son notables, lo que en parte explica la diferencia de precios. Ya se ha visto que los costos de las obras podían variar al margen de su calidad. Sin embargo, en este caso las diferencias de calidad fueron determinantes para las variaciones de valor económico.

Las pinturas enconchadas más caras de este inventario fueron "Dos tableros de concha de a vara en cuadro con sus marcos de lo mismo, en veinte y cuatro pesos ambos"; mientras que las más baratas se describieron como "Otros dos tapleros [sic] de concha de una tercia de alto y de ancho una cuarta con sus marcos de lo mismo, de San Joseph y La Virgen, a diez reales cada uno". Es decir, las que se tasaron a doce pesos medían unos $83.59 \mathrm{~cm}$ por lado, mientras que las que alcanzaron diez reales, $27.86 \mathrm{~cm}$ de alto y $2 \mathrm{I} \mathrm{cm}$ de ancho. Todas tenían marcos de concha.

Las primeras recuerdan por sus medidas al San Esteban que cuatro años atrás también se tasó en I2 pesos en el inventario de bienes del contador Bentura de Paz. Esto sugiere que su calidad fue buena porque el contraste de precio con las obras tasadas a diez reales es demasiado pronunciado como para suponer que obedece tan sólo al tamaño. Recuérdese que en el contrato de Juan González de 1699, las diferencias de costo entre las obras de distinto tamaño no son tan grandes. En el inventario de bienes de Olmedo y Luján, el valor especialmente bajo de los últimos ejemplares permite afirmar que no fueron de calidad destacada.

Los otros ejemplares registrados en este documento oscilan entre ambos extremos tanto en precio como en tamaño. Fueron descritos como "Otros dos tableros en media vara de alto y una tercia de ancho con su marco de concha de la Presentación el uno, y el otro de la Visitación, a cinco pesos los

67. De Marchi y Van Migroet, "Art, Value and Market Prices", 150.

68. Elisa Vargaslugo, Gustavo Curiel et al., Juan Correa, su vida y su obra, t. III, Cuerpo de documentos (México: Universidad Nacional Autónoma de México-Instituto de Investigaciones Estéticas, I99I), I47-I48. 
dos", "Otros dos tableros de concha con sus marcos de lo propio de media vara de alto y tercia poco más de ancho, de San Pedro y San Pablo, a cuatro pesos apreciados cada uno. 8 pesos" y "Otros dos tableros de concha de media vara de ancho y una tercia de largo con sus marcos de lo mismo, de San Jerónimo y otro de San Juan, a veinte reales cada uno. 5 pesos". Aunque las diferencias del monto entre estas obras no son pronunciadas, merecen atención, pues sus medidas son muy similares: 41.7 por $27.86 \mathrm{~cm}$, con variaciones en el formato.

Las seis obras no sólo midieron casi lo mismo, sino que también coincidieron en la presencia de marcos enconchados. Así pues, aunque el documento no menciona explícitamente la calidad o estado de conservación de ninguna de las tablas, cabe afirmar que el San Pedro y el San Pablo estaban en mejores condiciones o tenían un trabajo más cuidadoso que las otras cuatro tablas, y que ésa es la razón de la diferencia de precios. Al parecer, cada par de obras corresponde a distintos ciclos pictóricos, de los que Olmedo y Luján sólo adquirió algunos ejemplares.

Los precios relativamente bajos sugieren que se trató de pinturas hechas para el mercado abierto. Quizá su trabajo haya sido similar al de una Virgen niña con sus padres, un San Agustín y un San Gregorio anónimos que se conservan en la capilla de San José de la Parroquia de San Bartolomé de Sevilla. Las tres obras poseen las mismas dimensiones, una factura similar y marcos iguales; es decir, se realizaron en conjunto. Es difícil saber cuál fue su aspecto original, pues se hallan muy oscurecidas por la oxidación del barniz. Las tres usan la línea de manera enfática y poseen marcos enconchados, cuya paleta es muy similar a la de las pinturas que enmarcan. Los marcos son en extremo sencillos y emplean el nácar (que ha perdido casi todo su brillo) en trozos irregulares, en las flores que pueblan la entrecalle. ${ }^{69}$ Así pues, los consumidores esperaban que las obras tuvieran marcos de concha y los artistas intentaron satisfacer sus expectativas, con resultados irregulares. Los ejemplos mencionados en el documento de Olmedo y Luján también pueden haber sido parecidos a un San Miguel arcángel anónimo, de colección particular, que mide 4I×30 cm (fig. I2). En este caso el marco incluye un sencillo trabajo de pintura y concha, que deja de lado la ornamentación habitual. En la pintura el nácar mantiene su brillo, pero el trabajo pictórico no es muy diestro. Casi toda la composición la ocupa

69. Las tres obras se reproducen en blanco y negro en María Concepción García Sáiz y Juan Miguel Serrera, "Aportaciones al catálogo de enconchados", en Cuadernos de Arte Colonial, núm. 6 (I990): 86. 
I2. Anónimo, San Miguel arcángel, siglo XvIII, ¿óleo? e incrustaciones de concha nácar sobre tabla, $4 \mathrm{I} \times 30$ $\mathrm{cm}$. Colección particular. Imagen tomada de $\mathrm{La}$ concha nácar en México (vid supra n. 2), II5.

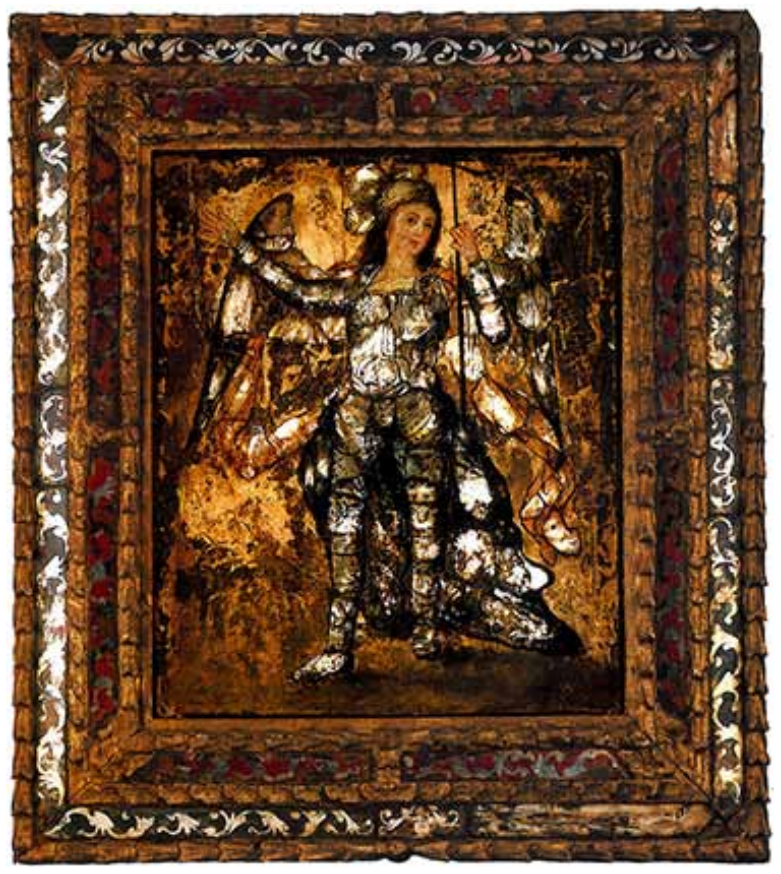

el San Miguel arcángel; el reducido fondo muestra vagas alusiones a un paisaje. La paleta es muy restringida y el rostro resulta poco detallado.

También otros consumidores mostraron especial interés por estas obras. Toussaint citó una mención de un inventario de bienes de 1709 a "Dos tableros de Nuestra Señora y Señor San José, ambos de concha. Dos láminas de concha de San Juan de Dios y San Esteban. Otras dos dichas de concha de Cena y Lavatorio. Quatro dichas [láminas] de concha de los quatro doctores. Dos tableritos de concha de San Pedro y San Pablo".70 Ignoramos de cuántas pinturas se componía esta colección pictórica, así como el precio y tamaño de los enconchados mencionados. Ahora bien, la existencia de I2 ejemplares sugiere un gusto particular por éstos.

70. Testamentaría de don José Bueno Basorí. Manuel Toussaint, "La pintura con incrustaciones de concha nácar en la Nueva España”, Anales del Instituto de Investigaciones Estéticas V, núm. 20 (1952): 9. 
I06

SONIA I. OCAÑA RUIZ

Aunque la mayoría de los documentos no menciona obras tan numerosas, a menudo las pinturas se describen de manera muy similar a la de los ejemplos anteriores. Aún no se han localizado inventarios de bienes novohispanos que mencionen series enconchadas de temática histórica. El mercado de la pintura novohispana tuvo particularidades en sus distintos segmentos y, al margen del uso de la concha, buena parte de la producción pictórica fue anónima y no correspondió a encargos específicos. Cuantitativamente, lo más representativo de la producción de enconchados fueron las obras de temática religiosa de entre 30 y $80 \mathrm{~cm}$, hechas para el mercado abierto, que a menudo se adquirieron de manera individual, o por pares.

\section{Las obras "ordinarias" y "muy ordinarias". Los precios bajos}

Si bien los ejemplares conservados permiten advertir cierta diversificación de calidad, dicha variedad resulta mucho más evidente en la información documental. Al respecto, la mejor fuente de información es un inventario de bienes de 1727 que registra "Dos lienzos y tableritos embutidos de concha con marcos de lo mismo, uno de la Huida a Egipto y otro de la Encarnación. Seis tableros de a media vara embutidos de concha con marcos de lo mismo ordinarios. Catorce liencecitos labrados de concha muy ordinarios" ${ }^{11}$ Se advierte que los tres grupos de obras tuvieron distintas calidades: el inventario no se pronuncia sobre las primeras, mientras que el calificativo "ordinarias" explícitamente alude a una calidad inferior y el de "muy ordinarias", a una calidad extremadamente baja.

El calificativo "ordinarias" permite descartar que las obras procedan de un taller familiarizado con este tipo de trabajo. Aún así, los seis tableros ordinarios poseyeron marcos enconchados; es decir, en todos los segmentos del mercado hubo consumidores que los consideraron como parte significativa de las obras. Es probable que las obras "ordinarias" hayan tenido importantes diferencias técnicas comparadas con las de mejor calidad. Al respecto, llama la atención la referencia a los lienzos. Las obras conservadas emplean como soporte la tabla (más apta para sostener el peso de la concha) y la mayoría de las menciones documentales se refieren a "tableros" o "láminas" de concha. La referencia al

7I. "Bienes de don Alonso Gutiérrez Deza y de su mujer Bernarda Bázquez difunta, I727”. Véase Toussaint, "La pintura con incrustaciones", 9. Las cursivas son mías. 
lienzo en relación con obras consideradas de mala calidad sugiere, en consecuencia, el trabajo de un artista que tenía poca experiencia con los enconchados.

Es imposible saber a ciencia cierta cómo fueron estos ejemplares, pues se han perdido. Los enconchados presentan muchos problemas de conservación, pues los fragmentos de concha tienden a desprenderse con el tiempo. En su mayoría, las obras conservadas muestran adaptaciones técnicas que sugieren familiaridad con este tipo de trabajo. A pesar de esto, muchas han sido intervenidas para evitar o detener el deterioro. Así pues, las mayores evidencias que tenemos de que los novohispanos consideraron ciertas obras de mala calidad son documentales.

Por otro lado, es interesante que el inventario de bienes en cuestión mencione un lote de 22 ejemplares. Entre los documentos localizados, éste es el que incluye mayor cantidad de obras, después de los de la marquesa de San Jorge y su tío el contador Bentura de Paz. El documento que nos ocupa corresponde a la época en que estuvieron activos Del Pino y López Calderón. Sin embargo, a juzgar por la calidad de los ejemplares firmados por esos artistas, cabe suponer que los ejemplares "ordinarios" de este documento fueron obra de artistas desconocidos. El gusto por estas obras propició que pintores sin renombre incursionaran ocasionalmente en esta producción y satisficieran parte de la demanda del mercado de bajo presupuesto. Años después de que concluyera el trabajo de los González, quienes gustaron de los enconchados tuvieron a su alcance obras de distintas calidades y precios.

Como en este inventario de bienes no se avaluaron las pinturas, es difícil saber qué precios se asociaron a las obras consideradas de mala calidad. Ahora bien, en la búsqueda documental se hallaron menciones a 244 ejemplares, procedentes de inventarios de bienes de entre 1692 y 1767 . Se omitieron los precios de 99 obras. Otras 47, de 1704-1734, se tasaron a dos pesos o menos. No hay duda de que presentaron facturas distintas: sus tamaños van de "una tercia de alto y de ancho una cuarta" a "poco menos de vara de alto y de ancho tres cuartas" $(27.86 \mathrm{~cm}$ de alto y de ancho $2 \mathrm{I} \mathrm{cm}$; poco menos de $83.59 \mathrm{~cm}$ de alto y de ancho $63 \mathrm{~cm}$ ).

Los precios más bajos se hallan en un inventario de bienes de 1727 que menciona " $Y t$ otras dos dichas [láminas] con sus marcos pintados en dos reales" y "Dos dichas [láminas] sobrepuestas de concha en tres reales ambas".72 También destacan estas menciones: "Yten, dos tableros de concha con Nuestra 
IO8

SONIA I. OCAÑA RUIZ

Señora de Belén, de poco menos de vara de alto y de ancho tres cuartas, que apreció en tres pesos ambos", "Yten, otros dos tableros de concha, con el Sueño de San Joseph y Adán y Eva en el paraíso, de media vara de alto y menos de dos tercias de ancho, que apreció en dos pesos ambos" (I7I2); "203 Yt. Dos cuadritos de concha con sus marcos de lo mismo avaluados en doce reales ambos" (I7I4) ${ }^{73}$ y "Un cuadrito de Nuestra Señora del Rosario, de a tercia, embutido, en 8 reales y "Un tablero de Felipe Quinto, embutido en concha, con los escudos de armas, en I2 reales" (I7I6).

El documento de 1727 no proporciona mayor información sobre las obras, pero el costo es tan reducido que no hay duda de que la calidad del trabajo fue pobre, o bien, los ejemplares estaban muy deteriorados. Por su parte, el documento de 1712 ofrece información sugerente, pues las obras de tema desconocido eran medianas — medían poco menos de $84.9 \mathrm{~cm}$ de alto y $62.4 \mathrm{~cm}$ de ancho-y sus precios (tres pesos ambas) fueron mucho más bajos que los de las obras de años y medidas similiares comentados en apartados anteriores. Esto permite suponer que su calidad fue pobre, aunque la mención nada dice al respecto. Por su parte, el Sueño de San Joseph y Adán y Eva en el paraíso medían cerca de $42.45 \mathrm{~cm}$ de alto y menos de $55.6 \mathrm{~cm}$ de ancho y se avaluaron en dos pesos ambas. Las diferencias de valor entre las cuatro obras no son muy significativas y probablemente corresponden a las de tamaño, más que a la calidad.

En la mención de 1714, el diminutivo revela que se trata de obras pequeńas, lo que en parte explica el precio bajo. Algo parecido se advierte en Nuestra Señora del Rosario de $27.8 \mathrm{~cm}$, tasada en ocho reales en el documento de 1716. En el mismo documento se valuó a I2 reales el tablero de Felipe Quinto del que no se proporcionaron otros detalles. Sin embargo, como en el documento de 1727, en este caso el monto es tan reducido que cabe descartar que se trate de piezas logradas.

No hay duda de que estos precios se deben, en buena medida, a la calidad de las obras. Sin embargo, conviene tener en cuenta que los distintos segmentos del mercado tuvieron dinámicas diferentes y dieron lugar a distintas circunstancias de adquisición —y, en consecuencia, de aprecio. De Marchi y Van Migroet han advertido que en el siglo XVII en los Países Bajos coexistieron dos métodos de subasta: el inglés, con valores al alza (preferido por los pintores agremiados) y el holandés, con costos a la baja, habitual en los negocios clandestinos fuera

73. AGN, Civil, vol. 134, exp. 3, f. 33, "Inventario de bienes del capitán Francisco Vélez (I7I4)". 
de regulación. ${ }^{74}$ La preferencia por cada método correspondía a mercados hasta cierto punto distintos, cada uno con propia clientela, método de ventas y rango de precios: el primero se asoció a las pinturas de buena calidad, y el segundo permitió movilizar grandes lotes de obras de calidad inferior. ${ }^{75}$

En el caso de los enconchados, las pronunciadas diferencias entre los precios más altos y los más bajos deben de haberse debido en parte a las circunstancias de producción y compra. Las ordenanzas del gremio de pintores de 1686 advirtieron "que sólo los maestros examinados puedan vender [...] las pinturas que ellos hicieren [...] por la poca reverencia y devoción que causan las malas hechuras y pinturas, y que haciéndose de cargazón por otros y dándolas a revender, se siguen los grandes inconvenientes que hasta aqui se han experimentado". ${ }^{6}$ Más allá de la calidad de las obras, los pintores que no tuvieron el reconocimiento del gremio, cuyos ejemplares circularon por medio de reventas, deben de haber tenido que aceptar precios más bajos que aquellos que trabajaron en el marco de la regulación oficial.

Entre los ejemplares conservados, son pocos los que muestran un trabajo lo bastante torpe como para suponer que puedan haberse considerado ordinarios o haberse tasado a precios tan bajos como los aquí discutidos. Sin embargo, existen algunos ejemplares de composición sencilla, en los que la concha apenas brilla. Tal es el caso de un San Jerónimo del Museo Franz Mayer (fig. 13). Los embutidos de concha, reservados a las vestiduras del personaje, se ven a simple vista bajo la capa pictórica poco cubriente. Los fragmentos son muy pequeños, de formas geométricas y bordes irregulares. Sin embargo, la obra apenas permite advertir la luminosidad asociada a esta producción.

La luminosidad también está ausente de un Salvator mundi anónimo, de colección particular (fig. I4). La pieza está deteriorada y conserva pocas incrustaciones de concha; se advierten también faltantes de capa pictórica en el fondo. La paleta es muy pobre y el dibujo sugiere el trabajo de un pintor poco experimentado, al margen del uso de la concha. Debido al estado de conservación de la obra, es difícil saber si el trabajo original tuvo cualidades hoy perdidas. En caso de que la falta de brillo sea original, cabe advertir que no todas las conchas son nacaradas. Incluso en las que sí poseen nácar, la iri-

74. De Marchi y Van Migroet, "Art, Value and Market Prices", 453.

75. Los autores señalan que debe haber habido algunos cruces entre ambos mercados, y que cabría esperar que los gremios favorecerían sólo el mercado "de calidad" y tratarían de mantener ambos mercados separados. De Marchi y Van Migroet, "Art, Value and Market Prices”, 453.

76. De Marchi y Van Migroet, "Art, Value and Market Prices", 453. 


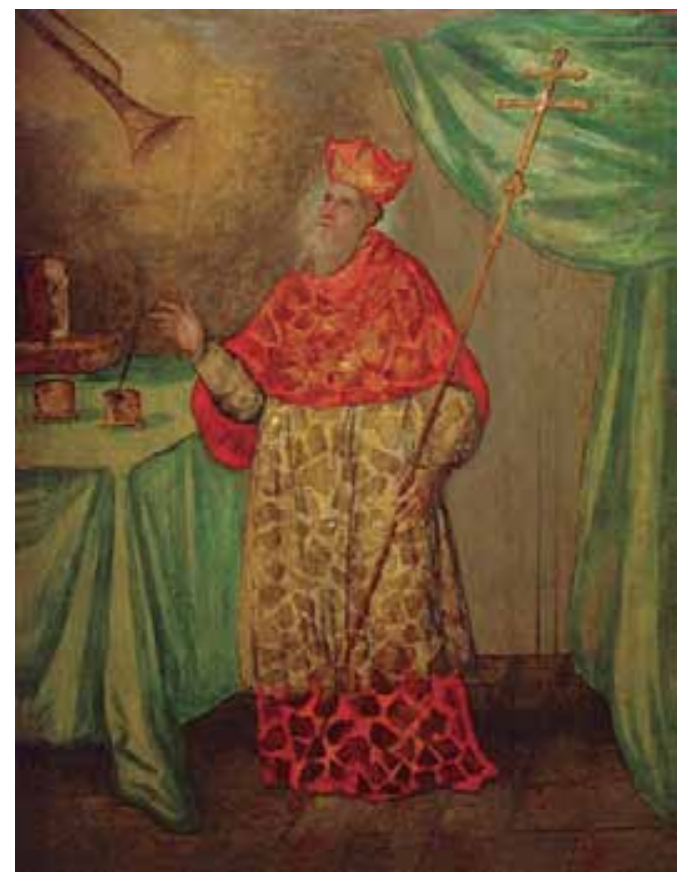

13. Anónimo, San Jerónimo, finales del siglo XVII-principios del XVIII, ¿óleo? e incrustaciones de concha nácar sobre tabla, $85 \times 64 \mathrm{~cm}$. Museo Franz Mayer.

discencia rara vez aparece en todo el objeto. Es posible que los artistas poco renombrados que en pocas ocasiones incursionaron en estas técnicas tuvieran problemas para aprovechar la luminosidad de las conchas nacaradas. En consecuencia, sus obras carecerían del brillo apreciado por los consumidores, lo que se percibiría como un trabajo de calidad inferior y daría lugar a precios más bajos.

\section{Conclusiones}

El hecho de que las pinturas incrustadas de concha hayan estado al alcance de buena parte de la sociedad capitalina demuestra que el fenómeno tuvo muchas aristas. Si bien su origen se liga a los González, los consumidores novohispanos tuvieron obras de características distintas, hechas por diferentes artistas. Las variaciones de precios registradas en los documentos son tan significativas que no se explican sólo por el tamaño de las piezas, la fecha de 
ENCONCHADOS: GUSTOS, ESTRATEGIAS Y PRECIOS

I4. Anónimo, Salvator mundi. Colección particular. Imagen tomada de La concha nácar en México (vid supra n. 2), I4I.

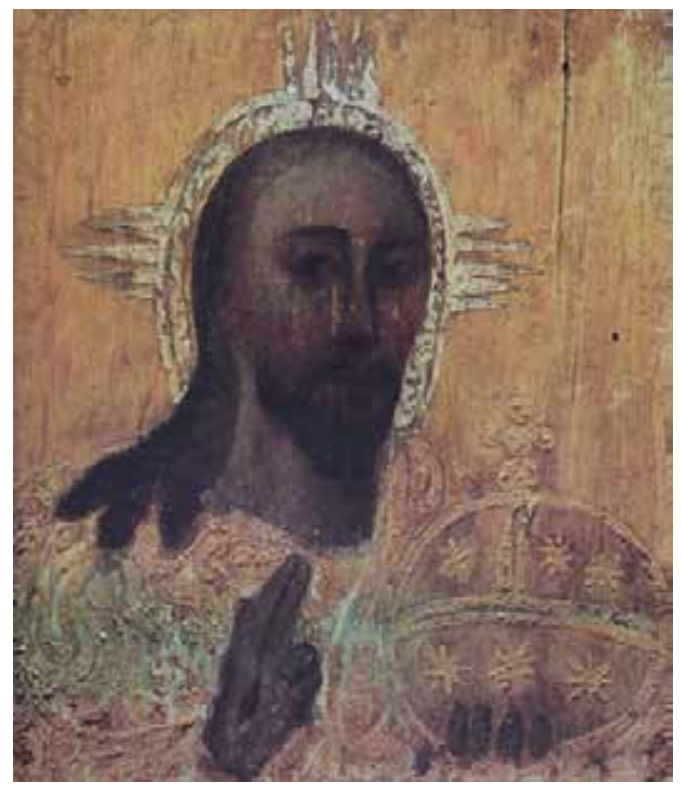

realización o la presencia y tipo de marcos, sino que también corresponden a la calidad de las pinturas. Aunque escasas, las referencias documentales a dicha calidad demuestran que el público tenía ideas concretas sobre lo que esperaban de este tipo de pinturas, más allá del mero uso de las incrustaciones de concha.

La información documental arroja luz a aspectos poco conocidos de la problemática de los enconchados. Con todo, el tema no se puede estudiar sólo desde este punto de vista. La paulatina aparición de numerosos ejemplares de características contrastantes permite hacer un análisis formal que nos ayuda a entender mejor este fenómeno pictórico el cual, como se vio, alcanzó cierto arraigo entre distintos grupos sociales capitalinos, pese a no haberse generalizado.

Desde luego es importante seguir estudiando esta modalidad pictórica tanto documental como formalmente. Ahora bien, nuestro conocimiento seguirá siendo fragmentario en tanto no se hagan estudios técnicos a los ejemplares de Correa, Del Pino, López Calderón, Rodulpho, además de las numerosas obras anónimas, que sin duda corresponden a distintos artistas. Más allá de registrar 
DOI: http://dx.doi.org/10.22201/iie.18703062e.2015.106.2541

II2

SONIA I. OCAÑA RUIZ

la existencia de piezas de diferentes facturas, conviene seguir discutiendo el papel que en su conjunto desempeñaron en el contexto pictórico novohispano. Estas obras nutren la reflexión sobre la problemática general de la pintura novohispana, pues si bien el gusto por las lacas japonesas fue común a distintos ámbitos, el desarrollo de los enconchados da cuenta de un marcado gusto por la originalidad. \$ 